\title{
41. ANTARCTIC NEOGENE RADIOLARIANS FROM THE KERGUELEN PLATEAU, LEGS 119 AND $120^{1}$
}

\author{
David Lazarus ${ }^{2}$
}

\begin{abstract}
Abundant, generally well-preserved radiolarians from Sites 737, 744, 745, 746, 747, 748, and 751 were used in stratigraphic analysis of Neogene, and particularly middle Miocene to Holocene, Kerguelen Plateau sediments. The composite Kerguelen section is more complete than the Weddell Sea sections recovered by Leg 113, and the radiolarians are better preserved. Leg 113 radiolarian zonations of Weddell Sea sites were applicable with only slight modification, and three new zones-Siphonosphaera vesuvius, Acrosphaera? labrata, and Amphymenium challengerae - are proposed for the latest Miocene. Geologic age estimates are given for all radiolarian zones used. Major hiatuses affecting most sites were seen within the middle Miocene, in the latest Miocene, and latest Pliocene. Five new species are described: Acrosphaera? labrata, Acrosphaera? mercurius, Siphonosphaera vesuvius, Actinomma? magnifenestra, and Helotholus? haysi.
\end{abstract}

\section{INTRODUCTION}

Radiolarians are one of the most important microfossil groups for Antarctic Neogene marine stratigraphy and paleoceanography. Initial studies based on piston cores and Deep Sea Drilling Project rotary drilled sections (Chen, 1974, 1975a, 1975b; Hays, 1965; Hays and Opdyke, 1967; Keany and Kennett, 1972; Keany, 1979; Lombari and Lazarus, 1988; Petrushevskaya, 1967, 1975; Weaver, 1976a, $1976 \mathrm{~b})$ provided descriptions of some of the more common species and established a preliminary stratigraphic framework for Neogene sections. The Pliocene-Pleistocene stratigraphy was calibrated to geologic time using paleomagnetic stratigraphy (Hays and Opdyke, 1967), but the Miocene stratigraphy was not calibrated because of incomplete sections, endemic forms, and a lack of good paleomagnetic data.

Knowledge of Antarctic radiolarians has improved in the last few years with the recovery and study of many highquality, hydraulic-piston-cored sections from the Falkland Plateau (Weaver, 1983) and Weddell Sea (Abelmann, 1990; Lazarus, 1990). This work has resulted in a refined radiolarian zonation for the Neogene (Abelmann, 1990; Lazarus, 1990), with a calibration of the radiolarian zonation to the geologic time scale, and new descriptions of Cretaceous radiolarian faunas (Ling, 1990; Ling and Lazarus, 1990).

Ocean Drilling Program (ODP) Legs 119 and 120 recovered many Paleogene and Neogene sections from the Kerguelen Plateau with abundant, well-preserved radiolarians, together with diatoms, calcareous microfossils, and paleomagnetic stratigraphy. These sections provide an opportunity to confirm and refine previous radiolarian stratigraphy, and to provide more complete sections across the middle Miocene and Miocene/Pliocene boundary hiatuses than those recovered by previous coring in the Antarctic.

Preliminary descriptions of Legs 119 and 120 radiolarian occurrences and stratigraphy are given by Caulet (in Barron, Larsen, et al., 1989; Barron et al., 1991) for Leg 119 radiolar-

\footnotetext{
${ }^{1}$ Wise, S. W., Jr., Schlich, R., et al., 1992. Proc. ODP, Sci. Results, 120: College Station, TX (Ocean Drilling Program).

${ }^{2}$ Geologisches Institut, ETH-Zentrum, CH-8092, Zürich, Switzerland.
}

ians and by Lazarus (in Schlich, Wise, et al., 1989). This report describes in more detail late middle Miocene to early Pliocene radiolarians from Legs 119 and 120, together with a preliminary survey of earlier Miocene radiolarian stratigraphy. Caulet (1991) treats the Pliocene-Pleistocene and Paleogene radiolarians of Leg 119, whereas Abelmann (this volume) gives a more detailed description of early to early middle Miocene radiolarians from Leg 120. Paleogene radiolarians from Leg 120 are described by Takemura (this volume). In this report radiolarian stratigraphy is covered fully; however, because of time limitations, taxonomic descriptions are kept to a minimum and will be presented more fully in a future report.

A species list with references to the original author and a recent illustration are given for all taxa mentioned in the text or tables. A map showing the location of all Leg 119 and 120 sites is given in Figure 1. Sites shown on this map but not discussed here had either very little Neogene section (Sites 749 and 750 ), recovered only late Pliocene to Pleistocene sediments (Site 736), or had too few or too poorly preserved radiolarians to warrant further study (i.e., all Prydz Bay sites).

\section{METHODS}

Shipboard examination of strewn slides from the $>63-\mu \mathrm{m}$ size fraction established a preliminary stratigraphy. More closely spaced samples of the $>63-\mu \mathrm{m}$-size fraction were prepared onshore using the strewn-slide method and the settling method of Moore (1973). Generally, a minimum of one third of one $24 \times 50 \mathrm{~mm}$ coverslip, and often the entire coverslip, was examined for stratigraphic species, depending on their abundance (i.e., generally between 1,000 and 10,000 individual radiolarians). Because taxonomic work was conducted in parallel with the stratigraphic study, some taxa recorded in more recently studied samples were not routinely recorded in samples examined early in the investigation. Although selected samples were rechecked for the presence or absence of key species after examining the preliminary range charts, some gaps remain in the range charts that may reflect incomplete data recording rather than an actual absence of species. Taxonomic descriptions are based on a minimum of several hundred observed specimens from at least two different locations. Measurements were taken from video prints and are accurate to $\sim 5 \%$ of the given value. 


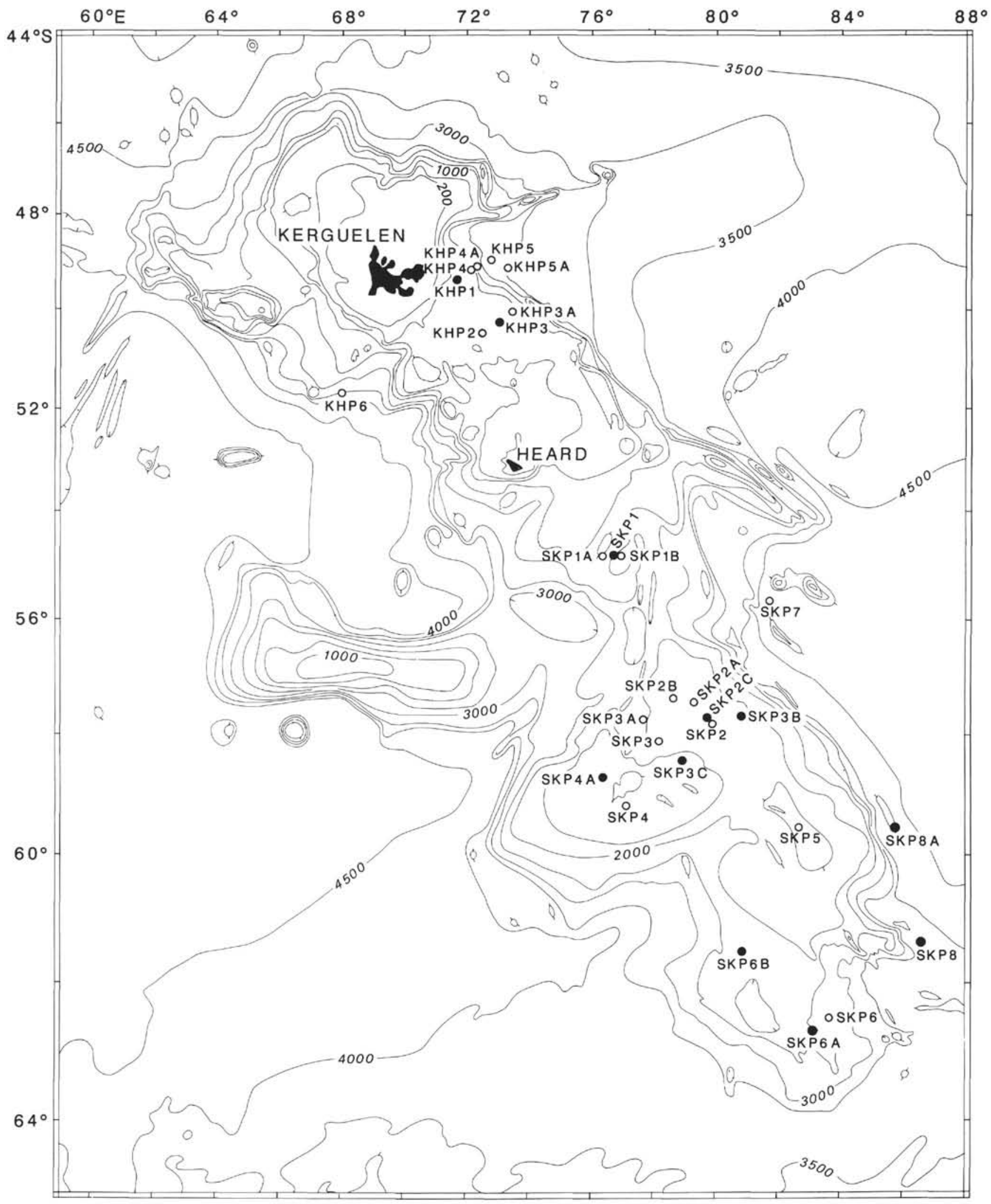

Figure 1. Map showing location of Legs 119 and 120 cores (from Schlich, Wise, et al., 1989). 


\section{STRATIGRAPHY}

Antarctic radiolarian zonation schemes were recently reviewed by Lazarus (Schlich, Wise, et al., 1989). Zonation of the Pliocene-Pleistocene interval by most workers, including Lazarus (1990), has generally followed (with some modifications) that of Hays (1965). The zonation of the Pliocene-Pleistocene interval used in this report is identical to that of Lazarus (1990), although the ages of some of the datums have been slightly revised, based on the results of Caulet (1991) from Leg 119. For the late middle and late Miocene, a revised zonation is presented, in part based on the earlier stratigraphic work of Chen (1975a, 1975b), Weaver (1983), and Lazarus (1990). The zonal scheme used for earlier Miocene Leg 119 material (A. golownini zone and older) is that described by Abelmann (this volume), who should be consulted for detailed information about these zones. Ages of Miocene datums are based on Leg 113 results (Gersonde et al., 1990) and the biostratigraphic/magnetostratigraphic syntheses of Legs 119 and 120 (Barron et al., 1991; Harwood et al., this volume). A summary of the zonation used in this report is given in Figure 2.

\section{DEFINITION OF ZONES}

Cycladophora antiqua Zone ( 22.4-21.0 Ma)

Base. First appearance datum (FAD) of Cycladophora antiqua Abelmann.

Top. FAD of Cyrtocapsella longithorax (Petrushevskaya) Abelmann.

Cyrtocapsella longithorax Zone (21.0-19.4 Ma)

Base. FAD of Cyrtocapsella longithorax.

Top. FAD of Cycladophora golli regipileus (Chen) Lombari and Lazarus.

Cycladophora golli regipileus Zone (19.4-17.3 Ma)

Base. FAD of Cycladophora golli regipileus.

Top. FAD of Eucyrtidium punctatum (Ehrenberg) Ehrenberg.

Eucyrtidium punctatum Zone (17.3-14.2 Ma)

Base. FAD of Eucyrtidium punctatum.

Top. FAD of Cycladophora humerus (Petrushevskaya) Lombari and Lazarus.

Cycladophora humerusZone (14.2-13.4 Ma)

Base. FAD of Cycladophora humerus.

Top. FAD of Actinomma golownini Petrushevskaya.

Actinomma golownini Zone (3.4-12.3 Ma)

Base. FAD of Actinomma golownini.

Top. FAD of Cycladophora spongothorax (Chen) Lombari and Lazarus.

This zone is divided into two subzones by the FAD of Dendrospyris megalocephalis Chen at $12.45 \mathrm{Ma}$.

Cycladophora spongothorax Zone (12.3-9.7 Ma)

Base. FAD of Cycladophora spongothorax.

Top. Evolutionary transition from Acrosphaera murrayana (Haeckel) Strelkov and Reshetnjak to Acrosphaera australis Lazarus.

This zone is divided into three subzones (lower, middle, and upper) by two datums. The lower/middle boundary is defined by the last appearance datum (LAD) of Actinomma golownini (10.2 Ma), and the middle/upper boundary by the FAD of Eucyrtidium pseudoinflatum Weaver $(10.0 \mathrm{Ma})$. The top of the $C$. spongothorax Zone is defined slightly differently from that of Lazarus (1990), where the FAD of $A$. australis was used to mark the top of the zone. Because rare individuals of $A$. australis can be found in some, but not all, sections even below the FAD of E. pseudoinflatum, the upper boundary of the $C$. spongothorax Zone is redefined as the point when A. australis becomes the dominant morphotype in transitional popu-

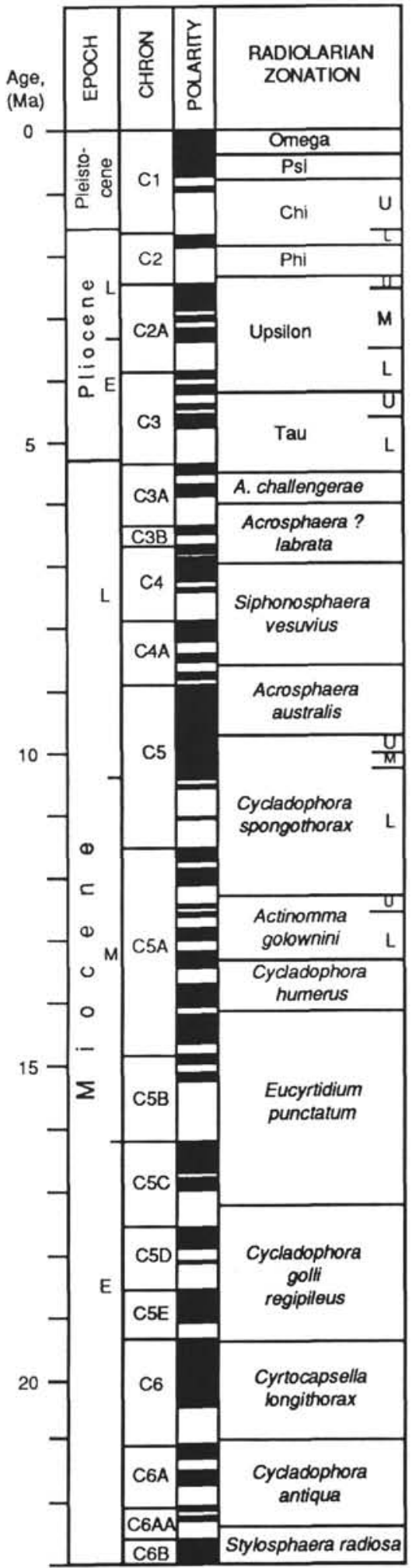

Figure 2. Summary of radiolarian zonation used in this report. $A$. golownini and lower zones are those of Abelmann (this volume). 
lations between it and its ancestor A. murrayana. The LAD of Cycladophora humerus occurs within the upper $C$. spongothorax Subzone at $\sim 9.9 \mathrm{Ma}$.

\section{Acrosphaera australis Zone (9.7-8.3 Ma)}

Base. Evolutionary transition from A. murrayana to A. australis. Top. LAD C. spongothorax.

Lithomelissa stigi Bjørklund, is a species with a discontinuous range in the Antarctic; it is absent in C. spongothorax Zone sediments but reappears and is present within this zone (FAD $\sim 9.0 \mathrm{Ma}, \mathrm{LAD}$ $\sim 8.5 \mathrm{Ma}$ ). The first common occurrence (FCO) of Stichocorys peregrina? (Riedel) Sanfilippo and Riedel occurs within the A. australis Zone at $\sim 8.4$ Ma. Earlier reports (Weaver, 1983; Caulet, 1991) placed the base of this species at $\sim 6.0 \mathrm{Ma}$, equal to the FAD of this form in low-latitude regions (Sanfilippo et al., 1985).

Siphonosphaera vesuvius Zone (8.3-7.0 Ma)

Base. LAD C. spongothorax.

Top. FAD Acrosphaera? labrata n. sp.

Helotholus haysi $\mathrm{n} . \mathrm{sp}$. and Siphonosphaera vesuvius $\mathrm{n} . \mathrm{sp}$. are generally present in this zone. The $\mathrm{LAD}$ of $S$. vesuvius occurs at or slightly above the top of this zone.

\section{Acrosphaera? labrata Zone (7.0-6.0 Ma)}

Base. FAD Acrosphaera? labrata.

Top. FAD Amphymenium challengerae Weaver.

Lithatractus timmsi?, generally absent in both the upper $C$. spongothorax Zone and the A. australis Zone, reappears and is present in much of the A.? labrata zone.

\section{Amphymenium challengerae Zone (6.0-5.5? Ma)}

Base. FAD A. challengerae.

Top. LAD A. challengerae.

The top of this species appears to be older than reported by Weaver (1983), who gave an age of $4.35 \mathrm{Ma}$. Note, however, that the calibration used here may be incorrect (see discussion of Site 745 under "Radiolarians at Each Site" below.

$$
\text { Tau Zone (5.5?-4.2 Ma) }
$$

Base. LAD A. challengerae.

Top. FAD $H$. vema.

This zone is subdivided into two subzones (lower and upper) by the last common occurrence (LCO) of Lychnocanium grande Campbell and Clark at 4.6 Ma. As noted previously by Lazarus (1990; see also Schlich, Wise, et al., 1989), this species generally occurs less commonly (rare to few) throughout most of the upper Tau Subzone. The consistency of this pattern in both the Weddell Sea and Kerguelen Plateau regions, and the highly variable (or even discontinuous) ranges of other Antarctic species such as L. timmsi?, Lithomelissa stigi, and A. golownini suggest that these relatively rare, late-occurring specimens are stratigraphically in situ and are not reworked.

\section{Upsilon Zone (4.2-2.3 Ma)}

Base. FAD of Helotholus vema Hays.

Top. LAD Helotholus vema.

This zone is subdivided into three subzones. The lower/middle boundary is defined by the LAD of Prunopyle titan Campbell and Clark at $3.3 \mathrm{Ma}$, whereas the middle/upper boundary is defined by the FAD of Cycladophora davisiana Ehrenberg at $2.5 \mathrm{Ma}$. The LAD of Desmospyris spongiosa Hays occurs at approximately the same time as the LAD of $H$. vema. The LAD of Lampromitra coronata Haeckel occurs within the lower? Upsilon Subzone at $\sim 3.5 \mathrm{Ma}$ and may be a more reliable event than the LAD of $P$. titan, which is rare in the upper part of its range. The FAD of $H$. vema can be hard to pick, as it is small and rare in the very earliest part of its range; it can also be confused with Helotholus haysi or with other species present in early Pliocene sediments. The FAD of H. vema in this report is defined as the first appearance of specimens with six regularly arranged radial beams within the thorax, a small thorax, and small, antarctissid type lattice wall pores.
Phi Zone (2.3-1.85 Ma)

Base. LAD of $H$. vema.

Top. LAD of Eucyrtidium calvertense Martin.

Chi Zone (1.85-0.8 Ma)

Base. LAD of $E$. calvertense.

Top. LAD of Pterocanium charybdeum trilobum (Haeckel) Lazarus, Scherer and Prothero.

This zone is subdivided into two subzones (lower/upper) by the LAD of Cycladophora pliocenica (Hays) Lombari and Lazarus at 1.7 Ma. The FAD of Triceraspyris antarctica (Haecker) Haecker occurs within or at the base of this zone at $\sim 1.8 \mathrm{Ma}$.

Psi Zone (0.8-0.4 Ma)

Base. LAD of Pterocanium charybdeum trilobum.

Top. LAD of Stylatractus universus Hays.

Omega Zone (0.4-0 Ma)

Base. LAD of Stylatractus universus.

Top. Holocene.

$S$. universus is rare in the upper part of its range, and its LAD is hard to pick without close sampling. The LAD of the much more common species Antarctissa cylindrica Petrushevskaya at $\sim 0.6 \mathrm{Ma}$ may be a more useful late Pleistocene marker.

\section{RADIOLARIANS AT EACH SITE}

\section{Site 737}

Neogene radiolarians at this site were rare in most samples because of dilution by abundant diatoms, or they contained non-age-diagnostic assemblages. Only a few samples of late Miocene age gave useful age information. Samples 119-737A$27 \mathrm{X}-2$ and $119-737 \mathrm{~B}-5 \mathrm{R}-2$ can be tentatively assigned to the $A$. australis Zone, based on the presence of common $C$. spongothorax, E. pseudoinflatum, rare A. australis, and very rare S. vesuvius. Sample 119-737B-6R-4 is assigned to the lower C. spongothorax Subzone, based on the common occurrences of $C$. spongothorax and A. golownini. The difference in zonal assignment between these samples suggests a low rate of sedimentation in this interval or a hiatus. Samples 119-737B7R-1 and -8R-2 contain common C. humerus, L. timmsi, and rare to few A. golownini and D. megalocephalis. $C$. spongothorax was not seen; thus, these samples were assigned to the upper A. golownini Subzone. Samples below this level were not examined.

\section{Site 744}

Site 744 , drilled in $2307 \mathrm{~m}$ water depth on the Southern Kerguelen Plateau, recovered a fairly condensed Neogene section of mixed calcareous and siliceous biogenic oozes (Table 1, microfiche, and Figure 3). Because of time and sampling limitations, only Cores $119-744 \mathrm{~A}-1 \mathrm{H}$ to $-10 \mathrm{H}$, from the less completely recovered Hole $744 \mathrm{~A}$ were used for radiolarian stratigraphic analysis. Radiolarians were abundant and well preserved in late Miocene to Holocene sediments; but, although abundant, they were only poorly to moderately preserved in earlier Miocene sediments. The $C$. longithorax, $C$. g. regipileus, $E$. punctatum, $C$. humerus, and $A$. golownini zones of Abelmann (this volume) can be recognized in this site. The Cycladophora antiqua Zone is tentatively recognized at the base of Core 119-744A-10H, although the occurrence of $C$. longithorax, whose FAD marks this zonal boundary, is too irregular to be confident of the event without further sampling. Poor recovery in Core 119-744A-9H prevents precise placement of the $C$. g. regipileus/C. longithorax boundary. 


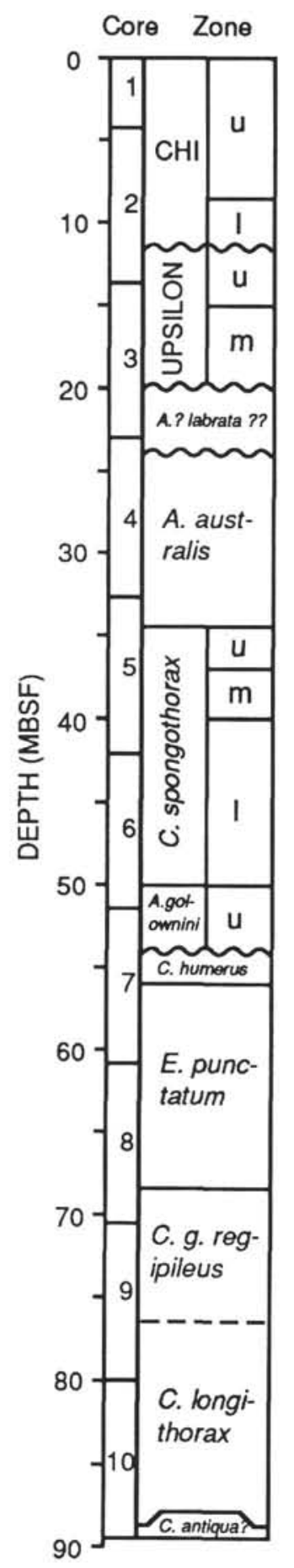

Figure 3. Radiolarian zonation, Site 744. Wavy lines $=$ hiatuses, dashed lines = uncertain placement of boundary, question marks = unzonable intervals; $\mathrm{u}=$ upper, $\mathrm{m}=$ middle, and $\mathrm{l}=$ lower subzones. See discussion of site in text for additional details.

There may be a short hiatus in the upper part of Core $119-744 \mathrm{~A}-7 \mathrm{H}$, as the lower subzone of the A. golownini Zone was not recognized. The later Miocene $C$. spongothorax and Acrosphaera australis zones were also recognized in Hole $744 \mathrm{~A}$, as were the three subzones of the $C$. spongothorax Zone. The Siphonosphaera vesuvius, Amphyenium challengerae, and Tau zones were not seen; they either lie in a very condensed interval between Samples 119-744A-3H-2, 53-55 $\mathrm{cm}$, and $-4 \mathrm{H}-1,52-54 \mathrm{~cm}$, or are absent in a hiatus. Sample 119-744A-4H-1, 52-54 cm, itself could be either late Miocene or early Pliocene in age, as reworking makes zonal assignment difficult. It is tentatively assigned here to the A.? labrata Zone (late Miocene).

Middle and upper Upsilon Zone assemblages in the upper part of Core 119-744A-3H were followed in Sample 119-744A$2 \mathrm{H}-4,53-55 \mathrm{~cm}$, by an assemblage assigned to the lower Chi Subzone. The Phi Zone was not seen; it is either lost in hiatus or is present in the unsampled interval between cores. Upper Chi assemblages were seen in Samples 120-744A-2H-3, 53-55 $\mathrm{cm}$, through the uppermost sample examined (Sample 119$744 \mathrm{~A}-1 \mathrm{H}-3,53-55 \mathrm{~cm})$.

\section{Sites 745 and 746}

Sites 745 and 746 (Table 2, microfiche, and Fig. 4) were drilled within $5 \mathrm{~km}$ of each other in approximately $4.1 \mathrm{~km}$ water depth. Site 745 was cored down to the latest Miocene. Drilling operations at this site were abandoned (because of approaching icebergs), and the ship's position was shifted to resume drilling at Site $\mathbf{7 4 6}$. Site 746 was washed down to the approximate level reached in the base of Site 745 , and then cored down to early late Miocene sediments. These two sites were treated as a single section in this report. The water depth at Site 746 is about $23 \mathrm{~m}$ less than at Site 745 , and this, together with slight differences in sedimentation history, make precise time equivalence in values of meters below seafloor (mbsf) unlikely. Diatom stratigraphic evidence (Barron, Larsen, et al., 1989) suggests that time equivalent levels in Site 745 are approximate $40 \mathrm{~m}$ below those in Site 746 . The existing radiolarian data does not provide additional information on this correlation, as the interval of overlap in the two sites appears to fall entirely within the $A$. challengerae Zone.

The Pliocene-Pleistocene section in Site 745 was studied in detail by Caulet (1991) and is not discussed here, except for the basal Pliocene interval.

The base of the early Pliocene lower Upsilon subzone was placed at the first appearance of taxonomically unquestionable specimens of Helotholus vema, between Samples 119-745B$19 \mathrm{H}-5,46-48 \mathrm{~cm}$, and $-19 \mathrm{H}-6,46-48 \mathrm{~cm}$. Helotholus vema is rare and sporadic in samples from Cores $120-745 \mathrm{~B}-19 \mathrm{H}$ and $-18 \mathrm{H}$, making the FAD of this species difficult to identify with accuracy. Caulet (1991), who also noted the difficulty in identifying this FAD, placed this event slightly higher, between Samples 119-745B-18H-5, 53-55 cm, and -18H-6, $53-55 \mathrm{~cm}$. All other zones and subzones, down to the $A$. australis Zone, were seen in this section. Three of these zones-the $A$. challengerae, $A$.? labrata, and $S$. vesuvius zones-are defined in this section for the first time. The lower/upper Tau Subzone boundary, based on the LCO of $L$. grande, is uncertain, as the LCO in the range chart coincides with an interval in which sample breakdown was poor and sample spacing large. However, if this range, and its prior age assignment, is accurate, then the lowermost two normal events in Site 745 are not Chron 3A, but Subchrons 3N3 and 3 N4. The last occurrence of $A$. challengerae would also then be significantly younger $(\sim 4.5 \mathrm{Ma})$ than the age adopted in this report $(5.5 \mathrm{Ma})$, and close to the $\sim 4.4-\mathrm{Ma}$ age for this event given by Weaver (1983). Finally, this interpretation would suggest the presence of a hiatus that removed Chron $3 \mathrm{~A}$ from both Sites 745 and 746 .

\section{Site 747}

Site 747 (Tables 3 and 4, microfiche; Fig. 5) was drilled at a water depth of $1696 \mathrm{~m}$ at $54^{\circ} 49^{\prime} \mathrm{S}$. It is the most northerly of the sites examined in this study. Two holes were cored at Site 


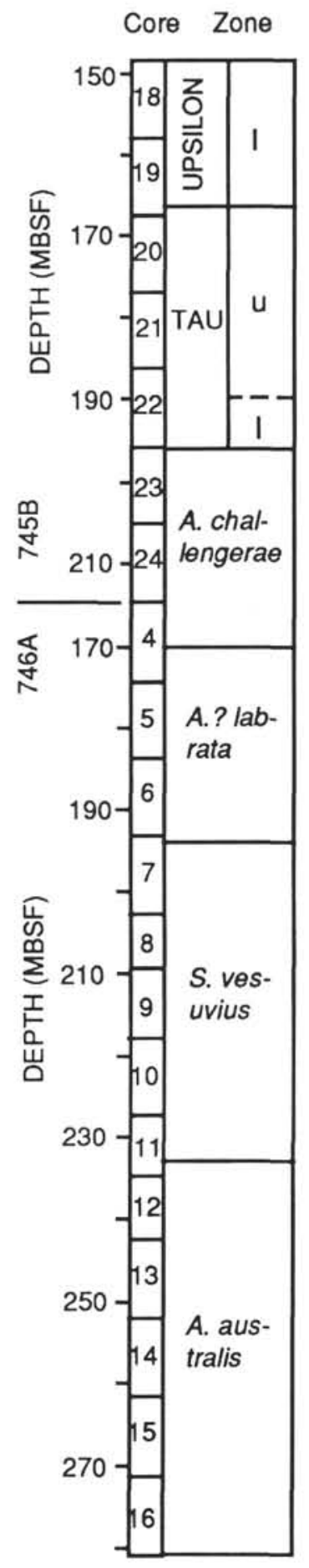

Figure 4. Radiolarian zonation, Sites 745 and 746 . Wavy lines $=$ hiatuses, dashed lines = uncertain placement of boundary, question marks $=$ unzonable intervals; $\mathrm{u}=$ upper, $\mathrm{m}=$ middle, and $\mathrm{l}=$ lower subzones. See discussion of site in text for additional details.

747. Hole 747A recovered a section down to the Late Cretaceous, whereas Hole $747 \mathrm{~B}$ ended at a much shallower subbottom depth in late Miocene sediments. In Hole $747 \mathrm{~A}$, the entire Neogene section was examined for radiolarian stratigraphy while on board ship at a resolution of approximately 4-5 samples/core. Additional shore-based work on the late middle Miocene to Holocene interval ( $\sim 0-60 \mathrm{mbsf})$ was

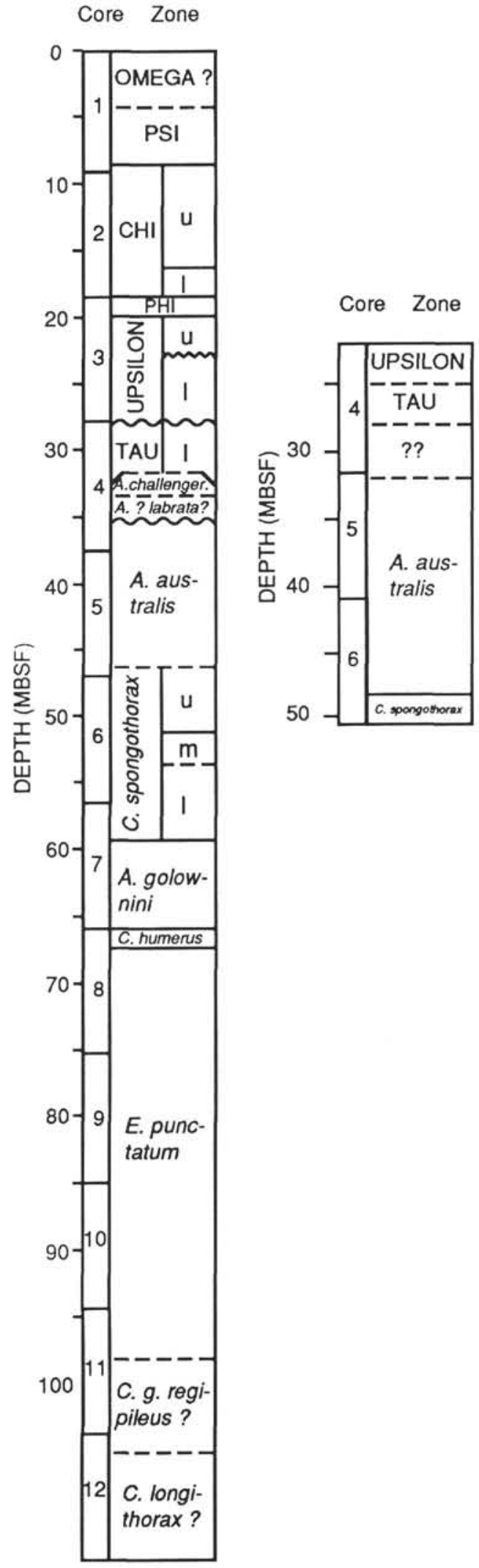

Figure 5. Radiolarian zonation, Site 747 . Wavy lines $=$ hiatuses, dashed lines = uncertain placement of boundary, question marks = unzonable intervals; upper $=$ upper, $\mathrm{m}=$ middle, and $\mathrm{l}=$ lower subzones. See discussion of site in text for additional details. 
conducted to improve stratigraphic resolution, while earlier Miocene sediments below this level were studied by Abelmann (this volume). Six cores were recovered from Hole 747B. The upper three cores contain late Pliocene to Holocene sediments and were not examined for this report. The early Pliocene and late Miocene section, however, was examined in detail ( $\sim 12$ samples/core).

Radiolarians in both holes are generally abundant and well preserved throughout the Pliocene to Holocene interval, whereas abundance and preservation are more variable in the Miocene. Radiolarian preservation is particularly poor in the early Miocene and latest Miocene. Although most radiolarian zones and subzones can be identified in Site 747, hiatuses or intervals of extremely condensed sedimentation are present, particularly in the latest Miocene and early Pliocene. The latest Miocene interval of reduced sedimentation or hiatus development coincides with an interval of unusually poor preservation (Hole $747 \mathrm{~A}, \sim 32-37 \mathrm{mbsf}$, and Hole 747B, $\sim 28-32 \mathrm{mbsf}$ ). Zonal markers in this interval are rare or absent, and precise zonal assignment is difficult. Differences in the zonal assignments in this interval between the two holes primarily reflect preservation and sampling and are not significant. The occurrence of $S$. universus is too sporadic to be confident of its LAD, and thus the presence of the Omega Zone at the top of Core $120-747 \mathrm{~A}-1 \mathrm{H}$ is uncertain. The occurrence of A. australis in Hole 747A (but, unaccountably, not in Hole 747B) is also very rare, and the FAD of this species may well be lower than indicated. This may account, in part, for the $A$. australis/C. spongothorax zonal boundary being $\sim 3 \mathrm{~m}$ lower in Hole $747 \mathrm{~B}$ than in Hole $747 \mathrm{~A}$, whereas most other biostratigraphic events in Hole $747 \mathrm{~B}$ are $\sim 4 \mathrm{~m}$ higher than in Hole $747 \mathrm{~A}$. Subzones within the $A$. golownini zone could not be identified, as the marker species D. megalocephalis was not seen in this interval. The identification of the lower Miocene $C$. g. regipileus and $C$. longithorax zones is tentative, being based only on shipboard data. Abelmann (this volume) leaves this interval unzoned. Abelmann (this volume) also places the boundary of the $E$. punctatum and $C$. humerus zones significantly lower (top of Core $120-747 \mathrm{~A}-9 \mathrm{H}$ ) than in this report (top of Core $120-747 \mathrm{~A}-8 \mathrm{H})$.

\section{Site 748}

Site 748 (Table 5, microfiche, and Fig. 6), located on the Southern Kerguelen Plateau, recovered a long sedimentary section, extending into the middle Cretaceous. Of the three holes drilled, Neogene sediments were recovered from Holes 748A and 748B. In Hole 748A, only two cores were taken, with sediments of Pleistocene to late Miocene age. Hole $748 \mathrm{~B}$ penetrated the entire Neogene. Upper Neogene sediments are more condensed in Site 748 than in other Leg 120 sites, and hiatuses are more extensive. Therefore, radiolarian analysis in this report was more limited than in the other sites, with the main goal being to identify the location and extent of these hiatuses. The largest of the hiatuses, at $\sim 11 \mathrm{mbsf}$ in Hole $748 \mathrm{~B}$, separates middle late Miocene sediments of the A. australis Zone from late early Pliocene sediments of the lower Upsilon Subzone. Another major hiatus between Samples 120-748B-5H-CC and -6H-1, $65-67 \mathrm{~cm}$, has removed all of the $A$. golownini and $C$. humerus zones. Significant reworking is seen in several levels at this site (e.g., late Pliocene, Sample 120-748B$2 \mathrm{H}-3$, top of section, which contains abundant reworked late Miocene radiolarians). Reworking is generally rare to absent in the other sites examined. Reworking and limited sample spacing are probably the reasons for the slight differences in zonal assignments between the two holes. The presence or

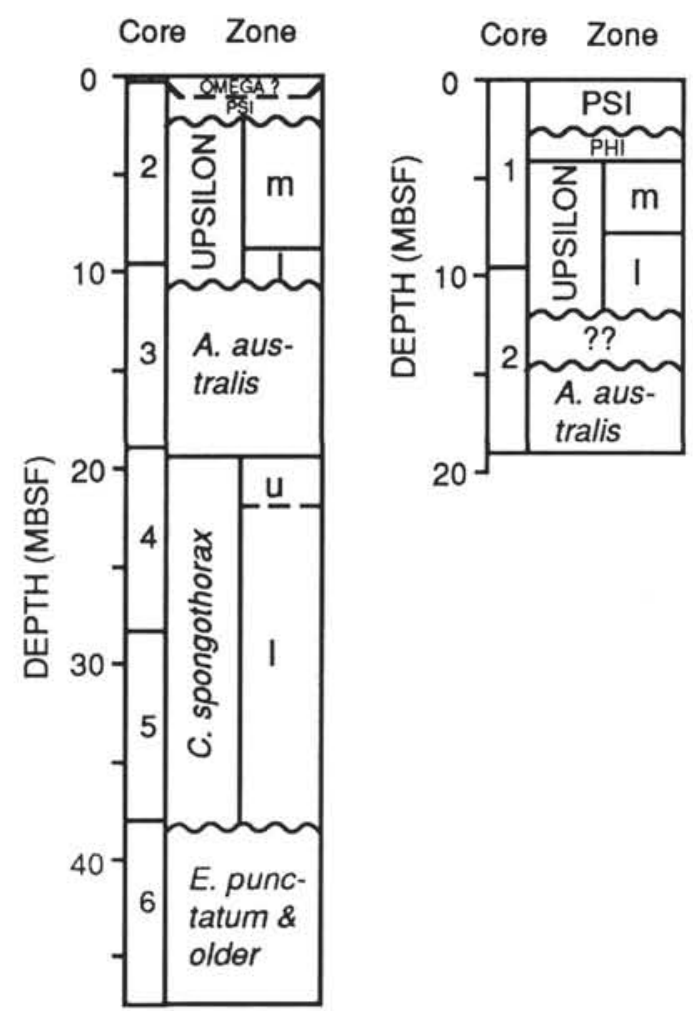

Figure 6. Radiolarian zonation, Site 748. Wavy lines $=$ hiatuses, dashed lines = uncertain placement of boundary, question marks = unzonable intervals; $\mathrm{u}=$ upper, $\mathrm{m}=$ middle, and $1=$ lower subzones. See discussion of site in text for additional details.

absence of a middle $C$. spongothorax Subzone cannot be determined without closer sampling, and may not be identifiable in any case because of reworking.

\section{Site 751}

Site 751 (Table 6, microfiche, and Fig. 7) recovered the thickest-Neogene section of Leg 120, and radiolarians are abundant and well preserved in all but the lowermost cores from the earlier Miocene. The late middle Miocene to Holocene interval (Cores $120-751 \mathrm{~A}-1 \mathrm{H}$ to $-12 \mathrm{H}$ ) was examined using $\sim 6$ samples/core. A hiatus and an interval of condensed sedimentation was seen in the lower part of Core 120$751 \mathrm{~A}-5 \mathrm{H}$ within the latest Miocene (S. vesuvius Zone to lower Tau Subzone). Latest Pliocene and early Pleistocene sediments (radiolarian $\mathrm{Phi}$ and $\mathrm{Chi}$ zones) were removed in another hiatus in the upper part of Core 120-751A-2H. Another hiatus or interval of reduced sedimentation was apparent between Samples 120-751A-12H-CC and -13H-CC. Abelmann's more detailed study of this interval (this volume) indicates the presence of the $C$. humerus Zone in the upper part of Core 120-751A-13H, and the absence of the lower $A$. golownini Subzone because of a hiatus between Samples $120-751 \mathrm{~A}-12 \mathrm{H}-\mathrm{CC}$ and $-13 \mathrm{H}-1,65-69 \mathrm{~cm}$.

\section{SUMMARY OF STRATIGRAPHY AND AGE OF RADIOLARIAN EVENTS}

The estimated age and location of all zonal and subzonal markers, as well as selected other biostratigraphic events, is given for each section studied in Table 7. Age estimates are based on a variety of sources, but all are based on calibration to the geomagnetic polarity time scale of Berggren et al. 


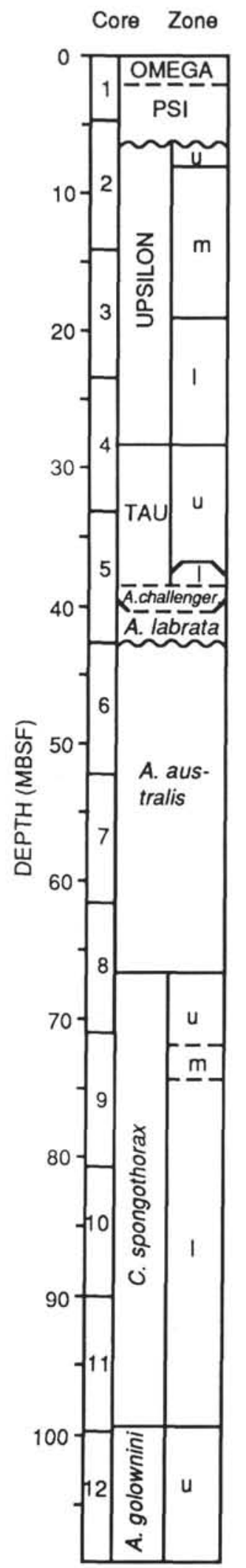

Figure 7. Radiolarian zonation, Site 751. Wavy lines = hiatuses, dashed lines = uncertain placement of boundary, question marks = unzonable intervals; $\mathrm{u}=$ upper, $\mathrm{m}=$ middle, and $\mathrm{l}=$ lower subzones. See discussion of site in text for additional details.
(1985). Pliocene and Pleistocene age estimates are derived from the biostratigraphic and magnetostratigraphic data given in Hays and Opdyke (1967) and Caulet (1991), with the exception of the LAD of Lampromitra coronata. The LAD of this species is very close to what is identified as the Gauss/Gilbert boundary in Holes 747A and 748B (Harwood et al., this volume). The LAD of $A$. challengerae is calibrated to the paleomagnetic stratigraphy interpretation of Barron et al. (1991) for Site 745. As noted in the discussion of this site (above), this age may be too old, as the LCO of L. grande, thought to be at paleomagnetic Subchron 3N3 in other sites, occurs at approximately the same level as the LAD of A. challengerae in Site 745. The age of the FAD of A. challengerae and FAD of A.? labrata are based on the paleomagnetic interpretation of Site 746 in Barron et al. (1991). The LAD of $C$. spongothorax is based on Site 746 paleomagnetic data, and data from Leg 113 Site 689 from the Maud Rise (Gersonde et al., 1990). The FADs of A. australis and $E$. pseudoinflatum and the LADs of $C$. humerus and $A$. golownini all occur within the long normal Magnetochron 5. Age assignments for these events are based on relative order in the section as well as on estimated sedimentation rates at Leg 113 and 120 sites. The FAD and LAD of $L$. stigi is calibrated in Site 747, but, because of its sporadic range, this calibration may not be reliable in other sites. It is noted primarily as an aid to between-hole correlations at Site 747.

\section{DISCUSSION AND SUMMARY OF RESULTS}

Sections from the Kerguelen Plateau cored during Legs 119 and 120 provide the most complete record yet of Neogene radiolarian stratigraphy in the Southern Ocean. Specifically, it appears that Kerguelen Plateau Neogene sections are more complete, and often have better preserved radiolarians, than those recovered from the Weddell Sea. The radiolarian stratigraphy used in the Weddell Sea region by Leg 113 (Abelmann, 1990; Lazarus, 1990) has proved to be applicable to the Kerguelen Plateau, although the more complete sections recovered from the Kerguelen Plateau have permitted refinement of the earlier stratigraphy. Neogene radiolarian zones appear to be valid throughout the Southern Ocean. Three new late Miocene zones-the Siphonosphaera vesuvius, Acrosphaera? labrata, and Amphymenium challengerae Zonesare defined for the first time. Hiatuses were seen in the middle Miocene, latest Miocene, and late Pliocene throughout the Southern Ocean, which make age interpretations slightly uncertain. However, most of the Miocene radiolarian datumlevels can now be calibrated with some confidence to the geomagnetic polarity time scale, using combined magneto-, bio-, and isotope stratigraphy (Table 7; Harwood et al., this volume).

\section{ACKNOWLEDGMENTS}

The author thanks the entire Leg 120 shipboard party for their help, during the cruise and onshore; Dr. Jean-Pierre Caulet for providing samples from Leg 119 and for helpful discussions about radiolarian stratigraphy and taxonomy; Dr. John Barron for providing much unpublished data from Leg 119 studies; Dr. Rainer Gersonde for providing his unpublished Leg 113 manuscript; Dr. Andrea Abelmann for agreeing to take responsibility for the shore-based study of the earlier Miocene Leg 120 samples; Kurt Meier for sample preparation; Drs. Catherine Nigrini, Kjell Bjørklund, and Joe Morley for reviews of earlier drafts; and Woody, for the invitation to participate on Leg 120. 
Table 7. Summary of radiolarian biostratigraphic data.

\begin{tabular}{|c|c|c|c|c|c|c|c|}
\hline Name & Age, $\mathrm{Ma}$ & Source of Age & $745+746$ & $745+746$ & $745+746$ & $745+746$ & 744 \\
\hline & & & Upper Depth & Lower Depth & Upper Sample & Lower Sample & Upper Depth \\
\hline LAD A. cylindrica & 0.61 & Caulet, 119 & 34 & 35.5 & $5-1,53$ & $5-2,53$ & 0 \\
\hline LAD P.c.trilobum & 0.8 & Hays\&Opdyk67 & 15 & 16.5 & $3-1,53$ & $3-2,53$ & 0 \\
\hline LAD C. pliocenica & 1.73 & Caulet, 119 & 84.5 & 86 & $10-3,53$ & $10-4,53$ & 7.73 \\
\hline FAD T. antarctica & 1.85 & Caulet, 119 & 90.4 & 90.5 & $10-7,53$ & $10-\mathrm{CC}$ & \\
\hline LAD E. calvertense & 1.85 & Caulet, 119 & & & & & 9.23 \\
\hline LAD H. vema & 2.32 & Caulet, 119 & 109.5 & 110 & $12-\mathrm{CC}$ & $13-1,53$ & 9.23 \\
\hline LAD D. spongiosa & 2.34 & Caulet, 119 & 110 & 111.5 & $13-1,53$ & $13-2,53$ & 9.23 \\
\hline FAD C. davisiana & 2.5 & Caulet, 119 & 114.5 & 116 & $13-4,53$ & $13-5,53$ & 14.23 \\
\hline LAD P. titan & 3.32 & Caulet, 119 & 130.5 & 132 & $15-2,53$ & $15-3,53$ & 15.73 \\
\hline LAD L. coronata & 3.5 & $120 \mathrm{Pmag}$ & & & & & \\
\hline FAD H. vema & 4.2 & Caulet, 119 & 153 & 155 & $18-4,53$ & $18-5,53$ & 15.73 \\
\hline LCO L. grande & 4.6 & 113Pmag & 188.53 & 191.53 & $22-2,53$ & $22-4,53$ & \\
\hline LAD A. challengerae & 5.5 & $745+6$ Pmag & 194.53 & 198.03 & $22-6,53$ & $23-2,53$ & \\
\hline FAD A. challengerae & 6 & $745+6$ Pmag & 169.83 & 171.33 & $4-4,53$ & $4-5,53$ & \\
\hline FAD A. labrata & 7 & $745+6$ Pmag & 192.96 & 195.33 & $6-7,53$ & $7-2,63$ & \\
\hline LAD C. spongothorax & 8.3 & $745+6$ Pmag & 232.33 & 233.83 & $11-4,53$ & $11-5,53$ & 23.72 \\
\hline FCO S. peregrina & 8.4 & $745+6$ Pmag & 247.23 & 252.33 & $13-4,53$ & $14-1,53$ & \\
\hline LCO L. stigi & 8.49 & 747Pmag & & & & & \\
\hline FCO L. stigi & 8.98 & 747Pmag & & & & & \\
\hline FAD A. australis & 9.7 & $113+120$ Pmag & & & & & 33.23 \\
\hline LAD C. humerus & 9.9 & $113+120$ Pmag & & & & & 33.23 \\
\hline FAD E. pseudoinflatum & 10 & $113+120$ Pmag & & & & & 36.23 \\
\hline LAD A. golownini & 10.2 & $113+120$ Pmag & & & & & 37.6 \\
\hline FAD C. spongothorax & 12.3 & $113+120$ Pmag & & & & & 47.23 \\
\hline FAD A. golownini & 13.4 & $113+120 \mathrm{Pmag}$ & & & & & 52.65 \\
\hline FAD D. megalocephalis & 12.45 & Abelmann, 120 & & & & & 52.65 \\
\hline FAD C. humerus & 14.2 & Abelmann, 120 & & & & & 55.23 \\
\hline FAD E.punctatum & 17.3 & Abelmann, 120 & & & & & 66.23 \\
\hline FAD C. g. regipileus & 19.4 & Abelmann, 120 & & & & & 71.3 \\
\hline FAD C. longithorax & 21 & Abelmann, 120 & & & & & 88.25 \\
\hline
\end{tabular}

Notes: FAD and $\mathrm{LAD}=$ first or last appearance datum; FCO and $\mathrm{LCO}=$ first or last common occurrence relative to other radiolarians in assemblage, or, for evolutionary transitions, to ancestor or descendant. Source of ages: Caulet, $119=$ Caulet $(1991)$; Abelmann, 120 = Abelmann (this volume). Pmag: paleomagnetic stratigraphic interpretations of respective ODP legs, as given in Gersonde et al. (1990), Barron et al. (1991), and Harwood et al. (this volume). Upper depth = upper sample bracketing biostratigraphic event, in meters below seafloor; Lower depth $=$ lower sample, in mbsf; Upper sample = upper sample name, in core, section, and interval format; Lower sample = lower sample name. Blank spaces in the table indicate events not seen or identifiable, or the absence of sediments of the appropriate age. See additional discussion in "Age of Radiolarian Events" section, this chapter.

\section{TAXONOMY}

Order SPUMELLARIA Ehrenberg, 1875

Family COLLOSPHAERIDAE Müller, 1858

Genus ACROSPHAERA Haeckel, 1881

Acrosphaera australis Lazarus, 1990, pp. 712-713, pl. 1, figs. 1-6.

Known range. middle late Miocene, circumantarctic, Southern Ocean; does not range into the very latest Miocene as indicated by Lazarus (1990).

Acrosphaera murrayana (Haeckel) Strelkov and Reshetnjak, 1971, p. 347, fig. 25; Lazarus, 1990, p. 713, pl. 2, figs. 3-4.

Acrosphaera? labrata n. sp. (Plate 1, Figs. 1-10)

Synonyms. Acrosphaera sp., Lazarus, 1990, p. 713, pl. 2, fig. 5; Collo-sphaerid sp., Keany, 1979. (Plate 1, Fig. 5)

Definition. Single spherical or elliptical shell, lacking spines of any sort, with fairly small, irregularly shaped, irregularly distributed pores. Many pores are surrounded by low, smooth, thick rims. Some specimens have more angular pores, and low straight ridges on the surface.

Etymology. From the latin labrum, rim or lip.

Occurrence. middle late Miocene to ?earliest Pliocene, Antarctic. Rare to abundant. Typically occurs as fragments rather than whole specimens.

Holotype. Sample 120-751A-5H-4, $48 \mathrm{~cm}, 81.4 / 32.7$.
Comments. Acrosphaera? labrata most resembles the primarily tropical to subtropical species Acrosphaera murrayana (Haeckel), but it has much thicker rims around the pores and lacks the corona of short spines typical of A. murrayana (Nigrini and Lombari, 1984). Most authors (Strelkov and Reshetnyak, 1971; Nigrini and Moore, 1979; Takahashi, 1981; Nigrini and Lombari, 1984) have included within A. murrayana specimens with coronal spines and radial tubes of varying lengths. Goll (1980) referred to specimens with coronal spines, but without even a short tube as $A$. murrayana, and specimens with a short tube as A. trepanata. The Antarctic material referred to as $A$. murrayana in this report would, under Goll's criteria, be $A$. trepanata. Rare specimens of typical low-latitude $A$. murrayana morphotypes, with fairly thin, low, raised rims and short coronal spines, were seen in middle late Miocene Sample 120-747B-4H-CC, near the base of the stratigraphic range of $A$.? labrata.

Early specimens of $A$.? labrata have very poorly developed rims and look much like specimens of $A$. murrayana without coronal spines. Thus, A.? labrata may have evolved in the late Miocene Antarctic from subantarctic populations of A. murrayana, although present observations are not sufficient to prove this conjecture. A.? labrata is questionably referred to the genus Acrosphaera because of this inferred evolutionary relationship to A. murrayana, although the lack of external spines in A.? labrata does not fit with the formal definition of the genus. The relative rarity of $A$.? labrata in northernmost Site 747 indicates a preference for more polar, antarctic-watermass conditions for this species. The present definition of A.? labrata 
Table 7 (continued).

\begin{tabular}{|c|c|c|c|c|c|c|c|c|}
\hline 744 & 744 & 744 & $747 \mathrm{~A}$ & $747 \mathrm{~A}$ & $747 \mathrm{~A}$ & $747 \mathrm{~A}$ & $747 B$ & $747 B$ \\
\hline Lower Depth & Upper Sample & Lower Sample & Upper Depth & Lower Depth & Upper Sample & Lower Sample & Upper Depth & Lower Depth \\
\hline 3.53 & top & $1-3,53$ & 7.95 & 9 & $1-6,45$ & $1-\mathrm{CC}$ & & \\
\hline 3.53 & top & $1-3,53$ & 7.95 & 9 & $1-6,45$ & 1-CC & & \\
\hline \multirow[t]{2}{*}{9.23} & $2-3,53$ & $2-4,53$ & 15.45 & 16.95 & $2-5,45$ & $2-6,45$ & & \\
\hline & & & 18.45 & 18.5 & $2-7,45$ & $2, \mathrm{CC}$ & & \\
\hline 14.23 & $2-4,53$ & $3-1,53$ & 18.45 & 18.5 & $2-7,45$ & $2, \mathrm{CC}$ & & \\
\hline 14.23 & $2-4,53$ & $3-1,53$ & 18.95 & 20.45 & $3-1,45$ & $3-2,45$ & & \\
\hline 14.23 & $2-4,53$ & $3-1,53$ & 18.95 & 20.45 & 3-1, 45 & $3-2,45$ & & \\
\hline 15.73 & $3-1,53$ & $3-2,53$ & 21.95 & 23.45 & $3-3,45$ & $3-4,45$ & & \\
\hline \multirow[t]{2}{*}{23.72} & $3-2,53$ & $4-1,52$ & 21.95 & 23.45 & $3-3,45$ & $3-4,45$ & & \\
\hline & & & 24.95 & 26.45 & $3-5,45$ & 3-6,45 & 21.8 & 23.62 \\
\hline \multirow[t]{5}{*}{23.72} & $3-2,53$ & $4-1,52$ & 28 & 29.95 & 3. CC & $4-2,45$ & 24.42 & 25.12 \\
\hline & & & 29.95 & 32.95 & $4-2,45$ & $4-4,45$ & & \\
\hline & & & 32.1 & 32.95 & $4-3,110 ?$ & 4-4,45? & & \\
\hline & & & 32.95 & 33.6 & $4-4,45 ?$ & $4-4,110 ?$ & & \\
\hline & & & 33.6 & 34.45 & $4-4,110$ & $4-5,45$ & 31.3 & 31.62 \\
\hline \multirow[t]{4}{*}{25.22} & $4-1,52$ & $4-2,59$ & 34.45 & 35.95 & $4-5,45$ & $4 \cdot 6,45$ & 31.62 & 32.42 \\
\hline & & & 37.5 & 41.62 & 4-CC & $5-3,112$ & 36.92 & 37.62 \\
\hline & & & 42.45 & 43.12 & $5-4,45$ & $5-5,112$ & 38.42 & 39.12 \\
\hline & & & 48.95 & 50.45 & $6-2,45$ & $6-3,45$ & 40.8 & 41.92 \\
\hline 36.23 & $5-1,53$ & $5-3,53$ & & & & & 47.93 & 48.62 \\
\hline 36.23 & $5-1,53$ & $5-3,53$ & & & & & & \\
\hline 37.6 & $5-3,53$ & $5-4,36$ & 50.45 & 51.95 & $6-3,45$ & $6-4,45$ & 48.62 & 49.43 \\
\hline 42.73 & $5-4,36$ & $6-1,53$ & 51.95 & 54.95 & $6-4,45$ & $6-6,45$ & 46.43 & 47.12 \\
\hline 52.65 & $6-4,60$ & $7-1,95$ & 58.45 & 59.45 & $7-2,45$ & $7-3,45$ & 49.96 & 50.3 \\
\hline 55.23 & $7-1,95$ & $7-3,53$ & 66 & 66.45 & 7. CC & $8-1,45$ & & \\
\hline 55.23 & $7-1,95$ & $7-3,53$ & & & & & & \\
\hline 56.73 & $7-3,53$ & $7-4,60$ & & & & & & \\
\hline 71.3 & $8-4,60$ & $9-1,60$ & & & & & & \\
\hline 80.73 & $9-1,60$ & $10-1,60$ & & & & & & \\
\hline 89.4 & $10-6,60 ?$ & $10-7,16 ?$ & & & & & & \\
\hline
\end{tabular}

is rather broad, including forms with rounded and rimmed pores and those with much more angular pores, forms with reduced rim development, and those with ridged surfaces. These latter morphotypes may well belong to another species, but more detailed work will be needed to determine if this is so.

Acrosphaera spinosa echinoides Haeckel, 1887, p. 100, pl. 8, fig. 1; Bjørklund Goll, 1979, pp. 1311-1312, pl. 1, figs. 12-13 only; pl. 4, figs. 1-4, 7, and 8. (Plate 5, Figs. 5-8)

Comments. This species (stratigraphic range not given in tables) appears to be restricted to earlier Miocene sediments, where it ranges from rare to few in abundance.

Acrosphaera? mercurius n. sp. (Plate 1, Figs. 11-16)

Definition. Medium to small spherical shell covered with numerous small, round, irregular size pores, which are distributed irregularly, often overlapping, and thus form small arcuate cusps that partially subdivide the enlarged double pore. Edges of pores rounded, not rimmed or funnelled; surface of shell rough, with low, sharp arcuate ridges and crests, which do not form a regular frame pattern. No spines. Shell wall of moderate thickness.

Etymology. Named after the planet Mercury, the impact-cratered surface of which resembles the dense, overlapping distribution of subcircular pores in this species.

Occurrence. middle Miocene to Pliocene. Rare and sporadic.

Holotype. Sample 120-747B-4H-3, $112 \mathrm{~cm}, 81.4 / 24.5$.

Comments. Placed in Acrosphaera because of the irregular pore distribution, absence of pore frames, internal shells, or spines, all characteristics of collosphaerids. However, this form, with its rough shell surface and unrimmed pores, is not very similar to other members of Acrosphaera, and the generic assignment is uncertain.

\section{Genus SIPHONOSPHAERA Müller, 1858}

Siphonosphaera vesuvius n. sp. (Plate 2, Figs. 1-8)

Synonyms. Acrosphaera sp., Lazarus, 1990, p. 713, pl. 2, figs. 1-2; Collosphaerid sp., Keany, 1979, pl. 1, fig. 4.

Definition. Single spherical, rarely elliptical, shell with numerous regularly spaced, fairly uniformly sized and shaped open ended, slightly concave conical tubes. Radial length of tubes generally equal to or slightly greater than diameter of pores at end of tubes. Concave curvature of tubes often merges at base of tubes into convex circular swellings of shell surface. Distance between pore centers typically between 2 and 3 times diameter of pores. Tube length $\sim 5 \%-10 \%$ of shell diameter. No spines. Shell surface smooth.

Etymology. Name refers to Mt. Vesuvius, a well-known Italian volcano with a shape similar to the pores of this species.

Occurrence. Early to middle late Miocene, Antarctic. Rare to abundant. May occur primarily either as fragments, or, in wellpreserved samples, as (nearly) complete shells. Does not range into earliest Pliocene as indicated in Lazarus (1990).

Holotype. Sample 120-747A-5H-3, $112 \mathrm{~cm}, 2.9 / 83.1$.

Comments. Similar to several species described by Haeckel (1887), but differs in size, shape, and spacing of conical tubes, according to Haeckel's descriptions and plates. Siphonosphaera conifera Haeckel has tubes with lengths greater than the diameter of the shell. $S$. cyathina Haeckel has distally flared pores. Ethmosphaera polysiphonia Haeckel and E. conosiphonia Haeckel have closely packed simple 
Table 7 (continued).

\begin{tabular}{|c|c|c|c|c|c|c|c|c|}
\hline 747B & 747B & $748 \mathrm{~A}$ & $748 \mathrm{~A}$ & $748 \mathrm{~A}$ & $748 \mathrm{~A}$ & 748B & 748B & 748B \\
\hline Upper Sample & Lower Sample & Upper Depth & Lower Depth & Upper Sample & Lower Sample & Upper Depth & Lower Depth & Upper Sample \\
\hline & & & & & & & & \\
\hline & & & & & & & & \\
\hline & & & & & & & & \\
\hline & & 1.95 & 3.45 & $1-2,45$ & $1-3,45$ & 3.1 & 4.6 & $2-3$, TOP \\
\hline & & 3.45 & 4.95 & $1-3,45$ & $1-4,45$ & 2.05 & 3.1 & $2-2,45$ \\
\hline & & 1.95 & 3.45 & $1-2,45$ & $1-3,45$ & 3.1 & 4.6 & $2-3, \mathrm{TOP}$ \\
\hline & & 3.45 & 4.95 & $1-3,45$ & $1-4,45$ & 3.1 & 4.6 & $2-3$, TOP \\
\hline & & 1.95 & 3.45 & $1-2,45$ & $1-3,45$ & 3.1 & 4.6 & $2-3$, TOP \\
\hline & & 3.45 & 4.95 & $1-3,45$ & $1-4,45$ & 2.05 & 3.1 & $2-2,45$ \\
\hline & & 6.45 & 9.5 & $1-5,45$ & $1-\mathrm{CC}$ & 8.05 & 9.6 & $2-6,45$ \\
\hline $3-\mathrm{CC}$ & $4-2,32$ & & & & & 6.55 & 8.05 & $2-5,45$ \\
\hline $4-2,112$ & $4-3,32$ & 11.45 & 12.95 & $2-2,45$ & $2-3,45$ & 10.05 & 11.55 & 3-1,45 \\
\hline & & & & & & & & \\
\hline & & & & & & & & \\
\hline & & & & & & & & \\
\hline 4-CC & $5-1,32$ & & & & & & & \\
\hline $5-1,32$ & $5-1,112$ & 12.95 & 14.45 & $2-3,45$ & $2-4,45$ & 10.05 & 11.55 & $3-1,45$ \\
\hline $5-4,112$ & $5-5,32$ & & & & & & & \\
\hline $5-5,112$ & $5-6,32$ & 12.95 & 14.45 & $2-3,45$ & $2-4,45$ & 10.05 & 11.55 & $3-1,45$ \\
\hline $5-\mathrm{CC}$ & $6-1,112$ & & & & & 19.55 & 21.05 & $4-1,45$ \\
\hline $6-5,113$ & $6-6,32$ & & & & & 19.1 & 19.55 & 3-CC \\
\hline & & & & & & 19.55 & 21.05 & $4-1,45$ \\
\hline $6-6,32$ & $6-6,113$ & & & & & 21.05 & 22.55 & $4-2,45$ \\
\hline $6-4,113$ & $6-5,32$ & & & & & 19.55 & 21.05 & $4-1,45$ \\
\hline $6-7,16$ & 6-CC & & & & & 38.1 & 38.75 & 5-CC \\
\hline & & & & & & 38.1 & 38.75 & $5-\mathrm{CC}$ \\
\hline & & & & & & & & \\
\hline & & & & & & & & \\
\hline & & & & & & & & \\
\hline & & & & & & & & \\
\hline & & & & & & & & \\
\hline
\end{tabular}

conical tubes. E. siphonosphaera Haeckel has a large number of pores set in hexagonal frames. Other collosphaerids with conical tubes, such as $S$, martensi Brandt (Takahashi, 1981) have, in addition to tubular pores, many pores without tubes.

Siphonosphaera magnisphaera? Takahashi, in press. (Plates 2, Figs. 9-10, and Plate 5, Figs. 11-14)

Comments. The forms seen in this study differ from those described by Takahashi (in press), having reduced or absent tubes around the main pores, and in having very small pores scattered over an almost hyaline shell surface. A specimen of $S$. magnisphaera from the Panama Basin is shown for comparison (Plate 5, Figs. 11-12; specimen courtesy of Dr. Takahashi).

Family ACTINOMMIDAE Haeckel, 1862, emend. Sanfilippo and Riedel, 1980

Genus ACTINOMMA Haeckel, 1860

Actinomma golownini Petrushevskaya, 1975, p. 569, pl. 2, fig. 16; Lazarus, 1990, p. 713, pl. 7, figs. 6-8.

Synonym. Actinomma tanyacantha Chen, 1974, pp. 481-482, pl. 1, figs. 1-2; Chen, $1975 \mathrm{a}$, p. 450 , pl. 11, figs. 5-6.

Comments. As noted in Lazarus (1990), A. golownini appears to evolve from a form (pl. 4, figs. 4, 9, and 13) with a more spherical cortical shell, and a more variable number of external spines.

Actinomma? magnifenestra n. sp. (Plate 3, Figs. 1-9)

Description. Single large cortical shell, no medullary shells observed. Cortical shell spherical or slightly irregular in shape. Lattice wall bars moderately thick, somewhat angular in cross section, weakly framed. Pores large, subcircular to strongly polygonal, vary in size but are fairly large relative to shell diameter. Several (10-30) short- to medium-length, tapered, three-bladed spines project from the surface of the shell.

Etymology. Latin, magni $=$ large and fenestra $=$ window, in reference to the large polygonal pores of this species.

Occurrence. Rare to common in early to middle Miocene Southern Ocean sediments.

Holotype. Sample 120-747A-6H-4, $45 \mathrm{~cm}, 11.5 / 102.0$.

Comments. A form similar to, but probably not conspecific to A.? magnifenestra is common in middle and late Miocene sediments (Plate 3, Figs. 10-12). This related form has more circular, smaller pores, and reduced or absent external spines. This species is tentatively placed in Actinomma, despite the absence of inner shells, because of the similarity of the cortical shell to other members of Actinomma (e.g., irregular pore shapes, numerous three-bladed spines, etc.). Correct generic assignment will require a revision of current generic definitions in actinommids, which are generally recognized to be highly artificial.

\section{Genus HEXALONCHE Haeckel, 1881}

Hexalonche philosophica? Haeckel, 1887, p. 186, pl. 22, fig. 4; Riedel and Sanfilippo, 1978, p. 104, pl. 2, fig. 8. (Plate 4, Figs. 1-3 and 5)

Synonym. Thecosphaera larnacium? Sanfilippo and Riedel, 1973, p. 521, pl. 3, figs. 13-14.

Comments. The specimen illustrated by Riedel and Sanfilippo (1978) appears to be very similar to the species seen in this study. The illustrated specimen of $H$. philosophica in Haeckel (1887) does not appear, however, to be very similar, lacking the heavy shell and 
Table 7 (continued).

\begin{tabular}{|c|c|c|c|c|}
\hline 748B & $751 \mathrm{~A}$ & $751 \mathrm{~A}$ & 751A. & $751 \mathrm{~A}$ \\
\hline \multirow[t]{2}{*}{ Lower Sample } & Upper Depth & Lower Depth & Upper Sample & Lower Sample \\
\hline & 1.5 & 2.56 & 1-1,BOT & $1-2,106$ \\
\hline 2-3,BOT & 5.68 & 7.18 & $2-1,98$ & $2-2,98$ \\
\hline 2-3,TOP & 2.56 & 3.45 & $1-2,106$ & $1-3,45$ \\
\hline 2-3,BOT & 5.68 & 7.18 & $2-1,98$ & $2-2,98$ \\
\hline $2-3, \mathrm{BOT}$ & 5.68 & 7.18 & $2-1,98$ & $2-2,98$ \\
\hline $2-3, \mathrm{BOT}$ & 7.18 & 8.68 & $2-2,98$ & $2-3,98$ \\
\hline $2-3$, TOP & 7.18 & 8.68 & $2-2,98$ & $2-3,98$ \\
\hline 2-CC & 18.18 & 19.68 & $3-3,98$ & $3-4,98$ \\
\hline $2-6,45$ & 14.2 & 15.18 & 2-CC & $3-1,98$ \\
\hline \multirow[t]{5}{*}{$3-2,45$} & 27.68 & 29.18 & $4-3,98$ & $4-4,98$ \\
\hline & 37.18 & 38.18 & $5-3,98$ & $5-4,48$ \\
\hline & 38.18 & 38.68 & $5-4,48$ & $5-4,98$ \\
\hline & 38.68 & 40.18 & $5-4,98$ & $5-5,98$ \\
\hline & 42.7 & 43.23 & $5-\mathrm{CC}$ & $6-1,53$ \\
\hline \multirow[t]{2}{*}{$3-2,45$} & 43.68 & 44.7 & $6-1,98$ & $6-2,50$ \\
\hline & 43.23 & 43.68 & $6-1,53$ & $6-1,98$ \\
\hline $3-2,45$ & 46.68 & 49.2 & $6-3,98$ & $6-5,50$ \\
\hline $4-2,45$ & 64.16 & 65.68 & $8-2,98$ & $8-3,98$ \\
\hline $4-1,45$ & 65.68 & 67.18 & $8-3,98$ & $9-4,98$ \\
\hline $4-2,45$ & 71.2 & 72.18 & $8-\mathrm{CC}$ & $9-1,98$ \\
\hline $4-3,45$ & 71.2 & 72.18 & 8-CC & $9-1,98$ \\
\hline $4-2,45$ & 73.68 & 75.18 & $9-2,98$ & $9-3,98$ \\
\hline $6-1,65$ & 98.68 & 99.7 & $11-6,98$ & $11-\mathrm{CC}$ \\
\hline $6-1,65$ & 109.2 & 118.7 & $12-\mathrm{CC}$ & $13-\mathrm{CC}$ \\
\hline & & & & \\
\hline & & & & \\
\hline & & & & \\
\hline & & & & \\
\hline
\end{tabular}

subcubical shape that characterizes this species. $T$. larnacium, as defined by Sanfilippo and Riedel (1973), shares several characteristics with the material encountered in this study, including a heavy, somewhat cubical cortical shell, two medullary shells, six threebladed internal beams, and weakly developed external spines. However, Sanfilippo and Riedel give a Paleocene to Eocene range for $T$. larnacium. Also, no "rosette"-shaped pores, mentioned as being common in $T$. larnacium, were seen in the current material.

Genus SPONGOPLEGMA Haeckel, 1881

Spongoplegma sp. ?, Chen, 1975a, p. 454, pl. 22, figs. 1-2. (Plate 5, Figs. 1-4)

Genus LITHATRACTUS Haeckel, 1887

Lithatractus timmsi? Campbell and Clark, 1944, p. 18, pl. 2, figs. 18-19. (Plate 4, Figs. 1-12)

Comments. Based on examination of North Pacific material (Lazarus, unpubl. observ.), the Antarctic specimens and Campbell and Clark's North Pacific species Lithatractus timmsi are conspecific. This species may have been previously described from Mediterranean Neogene sediments by Carnevale (1908) as Stauroxiphos communis, but it is impossible to be certain from the description and illustration in that publication. Riedel and Sanfilippo (1978) do not mention this species in their work on lower Pliocene radiolarians from the Mediterranean, but they do illustrate a similar form: Druppatractus irregularis Popofsky, 1912. Direct comparisons between new material from all these regions may be needed to determine the valid name.

\section{Genus STYLATRACTUS Haeckel, 1887}

Stylatractus universus Hays, 1970, p. 215, pl. 1, fig. 1; Lazarus, 1990, p. 717 , pl. 6, figs. 9-11.

Synonym. Stylatractus sp. Hays, 1965, p. 167, pl. 1, fig. 6 .
Stylatractus santaennae (Campbell and Clark) Petrushevskaya and Kozlova, 1972, p. 520, pl. 11, fig. 10. (Plate 4, Figs. 6-8)

\section{Genus AMPHISTYLUS Haeckel, 1881}

Amphistylus angelinus (Campbell and Clark) Chen, 1975a, p. 453, pl. 21, figs. 3-4.

Synonym. Axoprunum angelinum (Campbell and Clark) Kling, 1973 , p. 634 , pl. 1, figs. $13-16$, pl. 6, figs. 14-18.

Comments. Nigrini and Lombari (1984) discuss some of the nomenclatural problems with this form. As noted in Lazarus (1990), Amphistylus angelinus appears to be ancestral to Stylatractus universus, with each form being useful stratigraphically.

Genus DRUPPATRACTUS Haeckel, 1887

Druppatractus hastatus Blueford, 1982, pl. 6, figs. 3-4.

Synonym. Druppatractus sp., Chen, 1975a, 1975b.

Genus STYLACONTARIUM Popofsky, 1912

Stylacontarium bispiculum Popofsky, 1912, p. 91, pl. 2, fig. 2; Chen, 1975 a, p. 454 , pl. 21 , figs. $1-2$.

\section{Genus SATURNALIS Haeckel, 1881}

Saturnalis circularis Haeckel, 1887, p. 131; Chen, 1975a, p. 454, pl. 24, fig. 2.

Family SPONGODISCIDAE Haeckel, 1862, emend. Riedel, 1967

Genus AMPHYMENIUM Haeckel, 1881

Amphymenium challengerae Weaver, 1983, p. 675, pl. 6, figs. 1-2. (Plate 6, Figs. 4-7)

Comments. Most specimens seen have more central shells and more segments in the arms than those described and illustrated in Weaver (1983). Amphiropalum ypsilon Haeckel, 1887, and the specimens referred to in this report as Amphymenium challengerae appear to be similar except for the distal bifurcation of the arms, for example, in mature specimens of $A$. ypsilon. This difference, that is, the generic distinction between Amphiropalum and Amphymenium, may not warrant generic rank, as considerable variation in this characteristic is seen even within A. ypsilon (Nigrini and Moore, 1979; Nigrini and Lombari, 1984). The range of this form in the Antarctic is quite restricted stratigraphically and appears to be a useful marker for the latest Miocene interval.

Genus CIRCODISCUS Kozlova in Petrushevskaya and Kozlova, 1972

Circodiscus ellipticus (Stöhr) group Petrushevskaya, 1975; Abelmann, 1990, p. 693 , pl. 3, fig. 8.

Genus SPONGOTROCHUS Haeckel, 1860

Spongotrochus glacialis Popofsky, 1908; Nigrini and Moore, 1979, p. S117, pl. 15, figs. 2a-d.

Genus RHOPALASTRUM Ehrenberg, 1847, emend. Petrushevskaya and Kozlova, 1972

Rhopalastrum spp. (Plate 6, Figs. 1-3)

Comments. Nigrini and Moore (1979) and Nigrini and Lombari (1984) do not accept the synonymy of several of Ehrenberg's genera proposed by Petrushevskaya and Kozlova (1972). Under the older, Ehrenberg system, the forms seen in this study may be assigned to either Dictyocorne Ehrenberg, 1860, or Hymenastrium Ehrenberg, 1847.

Family COCCODISCIDAE Haeckel, 1862, emend. Sanfilippo and Riedel, 1980

Genus DIARTUS Sanfilippo and Riedel, 1980

Diartus sp. (Plate 6, Figs. 8-9)

\section{Genus DIDYMOCYRTIS Haeckel, 1860}

Didymocyrtis sp. (Plate 6, Figs. 10-14)

Comments. These two genera contain many forms important in low-latitude stratigraphy, and Antarctic occurrences have been employed to date Antarctic sediments (Weaver, 1983). The specimens 
seen in Antarctic Miocene sediments, however, although very similar to low-latitude taxa, are morphologically not quite the same, and thus may not have the same stratigraphic range. Given these differences (size of polar caps, length of polar columns, shape of cortical shell, etc.), precise species assignment (and age interpretation) is deferred.

\section{Family PYLONIIDAE Haeckel, 1881}

Genus PRUNOPYLE Dreyer, 1889

Prunopyle titan Campbell and Clark, 1944, p. 20, pl. 3, figs. 1-3; Lazarus, 1990, p. 717, pl. 5, figs. 1-4.

Prunopyle hayesi Chen, 1975a, p. 454, pl. 9, figs. 3-5; Lazarus, 1990, p. 717 , pl. 5, figs. 5-8.

\section{Order NASSELLARIA Ehrenberg, 1875 \\ Suborder SPYRIDA Ehrenberg, 1847, emend. Petrushevskaya, 1971}

Genus DESMOSPYRIS Haeckel, 1881

Desmospyris rhodospyroides Petrushevskaya, 1975, p. 593, pl. 10, figs. 27-29, 31, and 32. (Plate 7, Figs. 3-4)

Synonyms. Dendrospyris haysi Chen, 1974, pp. 482-483, pl. 2, figs. $3-5$; 1975 a, p. 455 , pl. 15 , figs. 3-5; Lazarus, 1990 , p. 716 , pl. 5 , figs. 9-12; Desmospyris? haysi Petrushevskaya 1975, p. 593, pl. 8, figs. $3-4$, pl. 27 , figs. $4-6$.

Desmospyris spongiosa Hays 1965, p. 173, pl. 2, fig. 1; Lazarus, 1990 , p. 716 , pl. 4, figs. 9-11.

\section{Genus DENDROSPYRIS Haeckel, 1881, emend. Goll, 1968}

Dendrospyris megalocephalis Chen, 1974 , p. 484 , pl. 2, figs. 6-7; 1975a, p. 455 , pl. 14, figs. 3-5.

Dendrospyris sp. cf. megalocephalis. (Plate 7, Figs. 1-2)

Genus TRICERASPYRIS Haeckel, 1881

Triceraspyris antarctica (Haecker), Haecker, 1908, pp. 445-446, pl. 84 , fig. 586; Chen, 1975, p. 456 , pl. 15, fig. 6.

Triceraspyris coronata Weaver, 1976a, p. 580, pl. 2, figs. 4-5, pl. 6, figs. 8-9. (Plate 7, Figs. 5-9)

Comments. As noted in Lazarus (1990), all of these spyrid species appear to be closely related to each other and often intergrade. An attempt was made in this study to assign populations to either $D$. spongios $a$ or $D$. rhodospyroides, based on the dominant morphotypes in the population. However, in some samples this was not possible, and the specimens are listed as either D. spongiosa? or D. rhodospyroides? in the range tables. $D$. rhodospyroides and $D$. haysi were lumped together in this report. Forms similar to D. megalocephalis, but with the apex of the cephalis still attached to the sagittal ring, were recorded as Dendrospyris sp. cf. megalocephalis. Forms with welldeveloped feet and reduced (or absent) abdomens were assigned either to Triceraspyris antarctica or $T$. coronata group. Specimens assigned to $T$. antarctica have large pores, long feet, and a wide cephalis, whereas specimens assigned to $T$. coronata group have a heavier, more equant cephalis, and somewhat stouter feet. The two forms do not show any stratigraphic overlap.

Family PLAGONIIDAE Haeckel, 1881, emend. Riedel, 1967

Genus ANTARCTISSA Petrushevskaya, 1967

Antarctissa cylindrica Petrushevskaya, 1975, p. 591, pl. 11, figs. 19-20; Lazarus, 1990, pl. 3, figs. 8-12.

Synonym. Antarctissa ewingi Chen, 1974, p. 486, pl. 3, figs. 4-6; 1975 a, p. 457 , pl. 16, figs. 5-9.

Antarctissa deflandrei (Petrushevskaya) Lazarus, 1990, p. 713, pl. 3, figs. 18-19.

Synonyms. Botryopera deflandrei Petrushevskaya, 1975, p. 592 , pl. 11, figs. 30-32; Antarctissa conradae Chen, 1974, p. 484, pl. 3, figs. $1-3 ; 1975$ a, p. 457 , pl. 17, figs. 1-5; Botryopera conradae (Chen) Petrushevskaya 1986, p. 193, fig. 2, no. 6 .

Antarctissa denticulata (Ehrenberg) Petrushevskaya, 1967, pp. 84-86, fig. 49, I-IV; Lazarus, 1990, pp. 713-714, pl. 3, figs. 1-4.
Antarctissa robusta Petrushevskaya 1975, p. 591, pl. 11, figs. 21-22; Lazarus, 1990, pp. 714-715, pl. 3, figs. 6-7.

Synonyms. Antarctissa antedenticulata Chen, 1974, p. 484, pl. 2, figs. $8-9$; 1975 a, p. 456 , pl. 18, figs. 1-2; ?Antarctissa equiceps (Campbell and Clark) sensu Petrushevskaya 1975, p. 591, pl. 11, figs. 23 and 25; ?Dictyocephalus equiceps Campbell and Clark, 1944, p. 46, pl. 6, fig. 15; ?Botryopera equiceps (Campbell and Clark) Petrushevskaya 1986 , p. 193.

Comments. Included with $A$. deflandrei in range chart tabulations in this report.

Antarctissa strelkovi Petrushevskaya, 1967, p. 89, pl. 51, figs. 3-6); Lazarus, 1990, pp. 713-715, pl. 3, figs. 13-15.

Comments. Some authors have provided separate stratigraphic data for A. strelkovi and A. longa (Popofsky) Petrushevskaya, 1967 (Petrushevskaya, 1975; Keany, 1979), whereas others have not (Chen, 1975a, 1975b; Weaver, 1976b, 1983). In this study no distinction was made between these forms.

Genus HELOTHOLUS Jörgensen, 1905

Helotholus vema Hays, 1965, p. 176, pl. 2, fig. 3, text fig. A; Lazarus, 1990 , p. 717 , pl. 7 , figs. $1-5$.

Synonym. Pseudocubus vema sensu Petrushevskaya, 1971, p. 46; Keany and Kennett, 1972; Kellogg, 1975.

Helotholus? haysi n. sp. (Plate 8, Figs. 1-17)

Description. Small, cap-shaped shell with very small, indistinct hemispherical cephalis and short cylindrical thorax. Lattice wall of both cephalis and thorax thin, with (relative to size of shell) large, irregularly shaped, irregularly distributed pores; bars thin, thorny, surface of shell rough. Horizontal ring inside thorax, connected to thorax wall by $7-10$ radial beams, and to base of cephalis by vertical beams.

Etymology. Named in honor of Dr. James D. Hays, for his many contributions to paleoclimate, evolution, and Antarctic radiolarian research.

Occurrence. Rare to few in the middle late Miocene (to early Pliocene?) of the Antarctic.

Holotype. Sample 120-746A-8H-3, 53-55 cm, 81.1/9.2.

Comments. Differs from the similar form $H$. vema in its small size, in having more radial beams ( $H$. vema usually has 6 or 7), relative to the diameter of the thorax, in having a larger internal ring, and, in general, in having a more variable morphology (irregularly shaped, noncircular internal rings, etc.). Lazarus (1990) noted the presence of a form in the basal Pliocene and Miocene of the Weddell Sea region that appears, at least in part, to be the same species, although the Pliocene specimens from the Weddell Sea region are much larger than those from the Kerguelen Plateau and may not be conspecific. The generic assignment of this species, and of $H$. vema, is uncertain. $H$. haysi appears to be congeneric with $H$. vema, as it differs from $H$. vema only in such details as lattice wall texture, number of internal beams, and overall size. Kellogg (1975) postulated an evolutionary origin for $H$. vema (which she calls Pseudocubus vema) from a form that Weaver (1983) named as a new species, Helotholus praevema. I have been unable to distinguish $H$. praevema from other members of the genus Antarctissa. It seems likely that the generic definition of Antarctissa will need to be revised, and these two species transferred to Antarctissa. See also comments in Lazarus (1990).

\section{Genus LITHOMELISSA Ehrenberg, 1847}

Lithomelissa stigi Bjørklund, 1976, p. 1125, pl. 15, figs. 12-17.

\section{Genus LAMPROMITRA Haeckel, 1881}

Lampromitra coronata Haeckel, 1887 group.

Comments. This group includes all forms with somewhat irregular pores (relative to Velicucullus sp. cf. oddgurneri below), well-developed basal fringes, and high conical shells. Includes forms described as Velicuculus altus n. sp. in Abelmann, 1990.

Genus VELICUCULLUS Riedel and Campbell, 1952

Velicucullus sp. cf. V. oddgurneri Bjørklund, 1976 
Comments. The use of this term is restricted in this study to forms with thin bars, circular to oval, regular pores, and only a rather delicate basal fringe located well inside the posterior margin of the shell.

Family THEOPERIDAE Haeckel, 1881, emend. Riedel, 1967

Genus CERATOCYRTIS Bütschli, 1882

Ceratocyrtis sp. (Plate 7, Figs. 10-17)

Comments. Large, broadly flared cone with large polygonal pores and, on some specimens, short thorns or spines projecting from the thorax lattice-wall surface. Cephalis very small, indistinct, with a short apical horn. Larger and more flared than the specimens of Sethoconus sp. illustrated by Chen (1975, p. 462, pl. 10, figs. 5-6), and no specimens were seen with external meshwork on the shell. Chen's written description, however, also includes specimens with more polygonal pores and spines rather than meshwork. Thus, the present species may represent a subdivision of Chen's broader species concept.

Genus CYCLADOPHORA Ehrenberg, 1872b, emend. Lombari and Lazarus, 1988

Cycladophora antiqua Abelmann, 1990.

Comments. This species was recorded separately only in Site 744 (Leg 119). In all other sites, it was included in $C$. golli golli.

Cycladophora bicornis (Popofsky) group, Lombari and Lazarus, 1988 , pp. 106-114, pls. 4 and 5.

Comments. No attempt was made in this report to distinguish subspecies in the group. Subspecies distributions within the Antarctic have been reported in Lombari and Lazarus (1988).

Cycladophora davisiana Ehrenberg 1872a, 1872b, pl. II, fig. 11.

Cycladophora golli (Chen) Lombari and Lazarus 1988, p. 124, pl. 11, figs. 1-12; Lazarus, 1990, pp. 715-716, pl. 4, fig. 8.

Cycladophora humerus (Petrushevskaya) Lombari and Lazarus 1988, p. 123, pl. 9, figs. 1-6; Lazarus, 1990, pp. 715-716, pl. 4, figs. 4-5.

Cycladophora pliocenica (Hays) Lombari and Lazarus 1988, p. 104; Lazarus, 1990, pp. 715-716, pl. 4, figs. 6-7.

Cycladophora spongothorax (Chen) Lombari and Lazarus 1988, p. 122, pl. 9, figs. 7-12; Lazarus, 1990, pp. 715-716, pl. 4, figs. 1-3.

\section{Genus PTEROCANIUM Ehrenberg, 1847}

Pterocanium charybdeum trilobum (Haeckel), Lazarus et al., 1985, pp. 195-196, fig. 10.

Pterocanium korotnevi (Dogiel), Nigrini, 1970, p. 170, pl. 3, figs. 10-11.

Genus LYCHNOCANIUM Ehrenberg, 1847

Lychnocanium grande Campbell and Clark, 1944, p. 42, pl. 6, figs. 3-6; Lazarus, 1990, p. 717, pl. 7, fig. 9.

Synonyms. Lychnocanium grande rugosum Riedel, 1952; Hays, 1965; Keany, 1979; Lychnocanoma grande rugosum (Riedel), Weaver, 1976a, 1976b, 1983.

Lychnocanoma conica (Clark and Campbell) group, Abelmann, 1990, p. 697. pl. 7, figs. 1a-b; Takemura, this volume, p. 751, pl. 2, figs. 13-14

Synonym. Lychnocanoma sphaerothorax Weaver, 1976a, p. 581, pl. 5, figs. 4-5.

\section{Genus DICTYOPHIMUS Ehrenberg, 1847}

Dictyophimus crisiae? group, Ehrenberg, 1854, p. 241; Nigrini, 1967, p. 66 , pl. 6 , figs. $7 \mathrm{a}-\mathrm{b}$.

Comments. Dictyophimus pocillum Ehrenberg (1875) may be a junior synonym of $D$. crisiae.

Genus EUCYRTIDIUM Ehrenberg, 1847

Eucyrtidium cienkowski Haeckel, 1887, p. 1493, pl. 80, fig. 9; Lazarus, 1990 , p. 716 , pl. 6 , figs. $1-3$.
Eucyrtidium calvertense Martin, 1904, p. 450, pl. 130, fig. 5; Lazarus, 1990 , p. 716, pl. 6, figs. 4-6.

Eucyrtidium pseudoinflatum Weaver, 1983, pp. 675-676, pl. 5, figs. 8-9; Lazarus, 1990, p. 716, pl. 6, figs. 12-14.

Genus CYRTOCAPSELLA Haeckel, 1887

Cyrtocapsella japonica (Nakaseko) Sanfilippo and Riedel, 1970, p. 452, pl. 1, figs. 13-15. (Plate 9, Figs. 1-8).

Comments. In addition to typical specimens of $C$. japonica (Plate 9, Figs. 5-6), a much more inflated form was also seen in this study (e.g., Plate 9, Figs. 2-4 and 7-8; Sample 120-747A-8H-4, 45-47 cm). These specimens appear to occur in approximately the same time interval as $C$. japonica sensu stricto, and so were lumped together in the range chart tables. They may, however, represent a different species. Relatively rare early Miocene specimens (Plate 9, Fig. 1) may also belong to a different species.

Cyrtocapsella tetrapera (Haeckel) Sanfilippo and Riedel, 1970, p. 435, pl. 1, figs. 16-18. (Plate 9, Fig. 11).

\section{Genus STICHOCORYS Haeckel, 1881}

Stichocorys peregrina? (Riedel) Sanfilippo and Riedel, 1970, p. 451, pl. 1 , fig. 10 .

Comments. The specimens seen in the Antarctic differ from typical $S$. peregrina and may not be conspecific. The Antarctic specimens have uniformly centrally inflated segments, increasing in size to at least the fifth segment, and are more heavily silicified than typical $S$. peregrina from low-latitude sediments.

Family PTEROCORYTHIDAE Haeckel, 1881, emend. Riedel, 1967 Genus STICHOPILIUM Haeckel, 1881

Stichopilium bicorne? Haeckel, 1887, p. 1437, pl. 77, fig. 9; Takahashi, 1981, p. 254, pl. 39, figs. 13-19. (Plate 9, Figs. 9-10 and 12-17).

Comments. Specimens included in this group may belong to more than one species. Differs from typical $S$. bicorne in that most specimens encountered in this study have fairly short, relatively narrow, nearly cylindrical thoraxes, and no posterior segments.

\section{REFERENCES}

Abelmann, A., 1990. Oligocene to middle Miocene radiolarian stratigraphy of southern high latitudes from Leg 113, Sites 689-690, Maud Rise. In Barker, P. F., Kennett, J. P., et al., Proc. ODP, Sci. Results, 113: College Station, TX (Ocean Drilling Program), 675-708.

Barron, J., Baldauf, J. G., Barrera, E., Caulet, J.-P., Huber, B. T., Keating, B. H., Lazarus, D., Sakai, H., Thierstein, H. R., and Wei, W., 1991. Biochronologic and magnetochronologic synthesis of ODP Leg 119 sediments from the Kerguelen Plateau and Prydz Bay, Antarctica. In Barron, J., Larsen, B., et al., Proc. ODP, Sci. Results, 119: College Station, TX (Ocean Drilling Program), 813-847.

Barron, J., Larsen, B., et al., 1989. Proc. ODP, Init. Repts., 119: College Station, TX (Ocean Drilling Program).

Berggren, W. A., Kent, D. V., and Van Couvering, J. A., 1985. The Neogene: Part 2. Neogene geochronology and chronostratigraphy. In Snelling, N. J. (Ed.), The Chronology of the Geological Record. Geol. Soc. London Mem., 10:211-260.

Bjørklund, K. R., 1976. Radiolaria from the Norwegian Sea, Leg 38 of the Deep Sea Drilling Project. In Talwani, M., Udintsev, G., et al., Init. Repts. DSDP, 38: Washington (U.S. Govt. Printing Office), 1101-1168.

Bjørklund, K. R., and Goll, R. M., 1979. Internal skeletal structures of Collosphaera and Trisolenia: a case of repetitive evolution in the Collosphaeridae (Radiolaria). J. Paleontol., 53:1293-1326.

Blueford, J., 1982. Miocene actinommid Radiolaria from the equatorial Pacific. Micropaleontology, 28:189-213.

Bütschli, O., 1882. Beitrage zur Kenntnis der Radiolarienskelette, insbesondere der Cyrtida. Z. Wiss. Zool., 36:485-540.

Campbell, A. S., and Clark, B. L., 1944. Miocene radiolarian faunas from southern California. Spec. Pap. Geol. Soc. Am., 51:1-76. 
Carnevale, P., 1908. Radiolarie e silicoflagellati di Bergonzano (Reggio Emilia). Veneto Sci. Lett. Arti Mem., 28:1-46.

Caulet, J. P., 1991. Radiolarians from the Kerguelen Plateau, ODP Leg 119. In Barron, J., Larsen, B., et al., Proc. ODP, Sci. Results, 113: College Station, TX (Ocean Drilling Program), 511-544.

Chen, P. H., 1974. Some new Tertiary radiolaria from Antarctic deep-sea sediments. Micropaleontology, 20:480-492.

1975a. Antarctic radiolaria. In Hayes, D. E., Frakes, L. A., et al., Init. Repts. DSDP, 28: Washington (U.S. Govt. Printing Office), 437-513.

1975b. Post Paleocene Antarctic radiolaria: their taxonomy, biostratigraphy and phylogeny, and the development of late Neogene cold-water faunas [Ph.D. dissert.]. Columbia Univ., New York.

Dreyer, F., 1889. Morphologische Radiolarienstudien, 1. Die Pylombildungen in vergleichend-anatomischer und entwicklungsgeschichlicher Beziehung bei Radiolaria und bei Protisten überhaupt, nebst System und Beschreibung neuer und der bis jetzt bekannten pylomatischen Spumellarien. Jena. Z. Naturwiss., 23:1-138.

Dumitrica, P., 1973. Cretaceous and Quaternary Radiolaria in deepsea sediment from the northwest Atlantic Ocean and Mediterranean Sea. In Ryan, W.B.F., Hsü, K. J., et al., Init. Repts. DSDP, 13: Washington (U.S. Govt. Printing Office), 829-901.

Ehrenberg, C. G., 1847. Über die mikroskopisch kieselschaligen Polycstinen als mächtige Gebirgsmasse von Barbados und über das Verhältnis der aus mehr als 300 neuen Arten bestehenden ganz eigentümlichen Formengruppe jener Felsmasse zu den jetzt lebenden Tieren und zur Kreidebildung. Eine neue Anregung zur Erforschung des Erdenlebens. Monatsber. K. Preuss. Akad. Wiss. Berlin, 40-60.

1854. Die systematische Charackteristik der neuen mikroskopischen Organismen des tiefen atlantischen Ozeans. Monatsber. K. Preuss. Akad. Wiss. Berlin, 236-250.

1860. Über den Tiefgrund des stillen Oceans swishchen Californien und den Sandwich-Inseln aus bis 15,600' Tiefe nach Lieut. Brooke. Monatsber. Kgl. Preuss. Akad. Wiss. Berlin, 819-833.

1872a. Mikrogeologischen Studien als Zusammenfassung seiner Beobachtungen des kleinsten Lebens der Meeres-Tiefgründe aller Zonen und dessen geologischen Einfluss. Monatsber. K. Preuss. Akad. Wiss. Berlin, 265-322.

$1872 \mathrm{~b}$. Mikrogeologischen Studien über des kleinsten Lebens der Meeres-Tiefgründe aller Zonen und dessen geologischen Einfluss. Abh. K. Preuss. Akad. Wiss. Berlin, 131-399.

1875. Fortsetzung der mikrogeologischen Studien als Gesamt-übersicht der mikroskopischen Paläontologie gleichartig analysierter Gebirgsarten der Erde, mit spezieller Rücksicht auf den Polycystinen Mergel von Barbados. Monatsber. K. Preuss. Akad. Wiss. Berlin, 1-225.

Gersonde, R., Abelmann, A., Burckle, L. H., Hamilton, N., Lazarus, D., McCartney, K., O'Brien, P., Spieß, V., and Wise, S. W., Jr., 1990. Biostratigraphic synthesis of Neogene siliceous microfossils from the Antarctic Ocean, ODP Leg 113 (Weddell Sea). In Barker, P. F., Kennett, J. P., et al., Proc. ODP, Sci. Results, 113: College Station, TX (Ocean Drilling Program), 915-936.

Goll, R. M., 1968. Classification and phylogeny of the Cenozoic Trissocyclidae (Radiolaria) in the Pacific and Carribean basins. Part I. J. Paleontol., 42:1409-1432.

1969. Classification and phylogeny of the Cenozoic Trissocyclidae (Radiolaria) in the Pacific and Caribbean basins. Part II. J. Paleontol., 43:322-339.

1976. Morphological intergradation between modern populations of Lophospyris and Phormospyris (Trissocyclidae, Radiolaria). Micropaleontology, 22:379-418.

1980. Pliocene-Pleistocene radiolarians from the East Pacific Rise and the Galapagos spreading center, Deep Sea Drilling Project Leg 54. In Rosendahl, B. R., Hekinian, R., et. al., Init. Repts. DSDP, 54: Washington (U. S. Govt. Printing Office), 425-453.

Haeckel, E., 1860. Abbildungen und Diagnosen neuer Gattungen und Arten von lebenden Radiolarien des Mittelmeeres. Monatsber. $K$. Preuss. Akad. Wiss. Berlin, 835-845.
1862. Die Radiolarien (Rhizopoda Radiaria): Berlin (Reimer).

1881. Entwurf eines Radiolarien-Systems auf Grund von Studien der Challenger-Radiolarien. Jena. Z. Naturwiss., 15:418472.

1887. Report on the Radiolaria collected by H.M.S. Challenger during the years 1873-1876. Rep. Sci. Results Voy. H.M.S. Challenger, Zool., 18:1-1803.

Haecker, V., 1908. Die Tripyleen, Collodarien und Mikroradiolarien der Tiefsee. Wiss. Ergeb. Dtsch. Tiefsee-Exped., 14:1-476.

Hays, J. D., 1965. Radiolaria and late Tertiary and Quaternary history of Antarctic seas. In Llano, G. A. (Ed.), Biology of the Antarctic Seas II, Am. Geophys. Union, Antarct. Res. Ser., 5:125-184. 1970. Stratigraphy and evolutionary trends of Radiolaria in North Pacific deep sea sediments. In Hays, J. D. (Ed.), Geological Investigations of the North Pacific. Mem. Geol. Soc. Am., 126:185-218.

Hays, J. D., and Opdyke, N. D., 1967. Antarctic radiolaria, magnetic reversals, and climate change. Science, 158:1001-1011.

Jörgensen, E., 1905. The protist plankton and diatoms in bottom samples: Radiolaria. Bergen Mus. Skr., 1:49-151.

Keany, J., 1979. Early Pliocene radiolarian taxonomy and biostratigraphy in the Antarctic region. Micropaleontology, 25:50-74.

Keany, J., and Kennett, J. P., 1972. Pliocene-early Pleistocene palaeoclimatic history recorded in Antarctic-Subantarctic deepsea cores. Deep-Sea Res. Oceanogr. Abstr., 19:529-548.

Kellogg, D. E., 1975. The role of phyletic change in the evolution of Pseudocubus vema (Radiolaria). Paleobiology, 1:359-370.

Kling, S. A., 1973. Radiolaria from the eastern North Pacific, Deep Sea Drilling Project, Leg 18. In Kulm, L. D., von Huene, R., et al., Init. Repts. DSDP, 18: Washington (U. S. Govt. Printing Office), 617-671.

Lazarus, D., 1990. Middle Miocene to Recent radiolarians from the Weddell Sea, Antarctica, ODP Leg 113. In Barker, P. F., Kennett, J. P., et al., Proc. ODP, Sci. Results, 113: College Station, TX (Ocean Drilling Program), 709-727.

Lazarus, D., and Pallant, A., 1989. Oligocene and Neogene radiolarians from the Labrador Sea, ODP Leg 105. In Srivastava, S. P., Arthur, M., Clement, B., et al., Proc. ODP, Sci. Results, 105: College Station, TX (Ocean Drilling Program), 349-380.

Lazarus, D. B., Scherer, R., and Prothero, D. R., 1985. Evolution of the radiolarian species-complex Pterocanium: a preliminary survey. J. Paleontol., 59:183-220.

Ling, H. Y., 1991. Cretaceous (Maestrichtian) radiolarians: Leg 114. In Ciesielski, P. F., Kristoffersen, Y., et al., Proc. ODP, Sci. Results, 114: College Station, TX (Ocean Drilling Program), 317-324.

Ling, H. Y., and Lazarus, D. B., 1990. Cretaceous radiolaria from the Weddell Sea: Leg 113 of the Ocean Drilling Program. In Barker, P. F., Kennett, J. P., et al., Proc. ODP, Sci. Results, 113: College Station, TX (Ocean Drilling Program), 353-363.

Lombari, G., and Lazarus, D. B., 1988. Neogene cycladophorid radiolarians from North Atlantic, Antarctic, and North Pacific deep-sea sediments. Micropaleontology, 34:97-135.

Lozano, J. A., and Hays, J. D., 1976. Relationship of radiolarian assemblages to sediment types and physical oceanography in the Atlantic and western Indian Ocean sectors of the Antarctic Ocean. In Cline, R. M., and Hays, J. D. (Eds.), Investigations of Late Quaternary Paleoceanography and Paleoclimatology. Mem. Geol. Soc. Am., 145:303-336.

Martin, G. C., 1904. Radiolaria. Maryland Geol. Surv. (Miocene), Gen. Ser., 447-459.

Moore, T. C., Jr., 1973. Method of randomly distributing grains for microscopic examination. J. Sediment. Petrol., 43:904-906.

Müller, J., 1858. Über die Thalassicollen, Polycystinen und Acanthometren des Mittelmeeres. K. Preuss. Akad. Wiss. Berlin, Abh., $1-62$.

Nigrini, C., 1967. Radiolaria in pelagic sediments from the Indian and Atlantic Oceans. Bull. Scripps Inst. Oceanogr., 11:1-125.

1970. Radiolarian assemblages in the North Pacific and their application to a study of Quaternary sediments in core V20-130. In Hays, J. D. (Ed.), Geological Investigations of the North Pacific. Mem. Geol. Soc. Am., 126:139-183. 
Nigrini, C., and Lombari, G., 1984. A Guide to Miocene Radiolaria. Spec. Publ. Cushman Found. Foraminiferal Res., No. 22.

Nigrini, C., and Moore, T. C., Jr., 1979. A Guide to Modern Radiolaria. Spec. Publ. Cushman Found. Foraminiferal Res., No. 16.

Petrushevskaya, M. G., 1967. Radiolarians of the orders Spumellaria and Nassellaria of the Antarctic region. In Andriiashev, A. P., and Ushako, P. V. (Eds.), Biological Reports of the Soviet Antarctic Expedition 1955-1958 (Vol. 3): Jerusalem (Israel Program for Sci. Transl.), 2-186.

1971. Radiolyarii Nassellaria v planktone Mirovogo okeana. In Bykhovshii, B. E. (Ed.), Radiolyarii Mirovogo Okeana po materialam Sovetskikh ekspeditisii. Issled. Fauny Morei, Leningrad (Nauka), 9:3-294.

1975. Cenozoic radiolarians of the Antarctic, Leg 29, DSDP. In Kennett, J. P., Houtz, R. E., et al., Init. Repts. DSDP, 29: Washington (U.S. Govt. Printing Office), 541-675.

1986. Evolution of the Antarctissa group. Mar. Micropaleontol., 11:185-195.

Petrushevskaya, M. G. and Kozlova, G. E., 1972. Radiolaria, Leg 14, Deep Sea Drilling Project. In Hayes, D. E., Pimm, A. C., et al., Init. Repts. DSDP, 14: Washington (U. S. Govt. Printing Office), 495-648.

Popofsky, A., 1908. Die Radiolarien der Antarktis (mit Ausnahme der Tripyleen). Dtsch. Sudpolar-Exped., 1901-1903, 10 (Zool. Vol. 2):183-305.

1912. Die Sphaerellarien des Warmwassergebietes. Dtsch. Sudpolar Exped., 1901-1903, 16 (Zool. Vol. 5):73-159.

Riedel, W. R., 1952. Tertiary radiolaria in western Pacific sediments. Goeteborgs K. Vetensk. Vitterhets-Samh. Handl., Ser. B, 3:1-22. 1967. Protozoa (Subclass Radiolaria). In Harland, W. B., et al. (Eds.), The Fossil Record. Geol. Soc. London, 291-298.

Riedel, W. R., and Campbell, A. S., 1952. A new Eocene radiolarian genus. J. Paleontol., 26:667-669.

Riedel, W. R., and Sanfilippo, A., 1978. Radiolaria. In Zachariasse, W. J., Riedel, W. R., Sanfilippo, A., Schmidt, R. R., Brolsma, M. J., Schrader, H. J., Gersonde, R., Drooger, M. M., and Broekman, J. A. (Eds.), Micropaleontological Counting Methods and Techniques-An Exercise on an Eight Metre Section of the Lower Pliocene of Capo Rossello, Sicily. Utrecht Micropaleontol. Bull., No. 17.
Sanfilippo, A., and Riedel, W. R., 1970. Post-Eocene "closed" theoperid radiolarians. Micropaleontology, 16:446-462.

1973. Cenozoic Radiolaria (exclusive of Theoperids, Artostrobids and Amphipyndacids) from the Gulf of Mexico, Deep Sea Drilling Project Leg 10. In Worzel, J. L., Bryant, W., et al., Init. Repts. DSDP, 10: Washington (U.S. Govt. Printing Office), 475-611.

1980. A revised generic and suprageneric classification of the Artiscins (Radiolaria). J. Paleontol., 54:1008-1011.

Sanfilippo, A., Westberg-Smith, M. J., and Riedel, W. R., 1985. Cenozoic radiolaria. In Bolli, H. M., Saunders, J. B., and PerchNielsen, K. (Eds.), Plankton Stratigraphy: Cambridge (Cambridge Univ. Press), 631-712.

Schlich, R., Wise, S. W., Jr., et al., 1989. Proc. ODP, Init. Repts., 120: College Station, TX (Ocean Drilling Program).

Strelkov, A. A., and Reshetnjak, V. V., 1971. Kolonialnie radiolarii Spumellaria mirovogo okeana. In Bykhovshii, B. E. (Ed.), Radiolyarii Mirovogo Okeana po Materialam Sovetskikh Ekspeditisii. Issled. Fauny Morey, Leningrad (Nauka), 9:295-369.

Takahashi, K., 1981. Vertical flux, ecology and dissolution of radiolaria in tropical oceans: implications for the silica cycle [Ph.D. dissert.]. Woods Hole Oceanographic Inst./MIT, MA.

, in press. Radiolaria: flux, ecology, and taxonomy in the Pacific and Atlantic. In Honjo, S. (Ed.), Woods Hole Oceanographic Inst. Press.

Weaver, F. M., 1976a. Antarctic Radiolaria from the southeast Pacific basin, Deep Sea Drilling Project, Leg 35. In Hollister, C. D., Craddock, C., et al., Init. Repts. DSDP, 35: Washington, (U.S. Govt. Printing Office), 569-603.

1976b. Late Miocene and Pliocene radiolarian paleobiogeography and biostratigraphy of the Southern Ocean [Ph.D. dissert.]. Florida State Univ., Tallahassee.

1983. Cenozoic radiolarians from the Southwest Atlantic, Falkland Plateau region, Deep Sea Drilling Project Leg 71. In Ludwig, W. J., Krasheninnikov, V. A., et al., Init. Repts. DSDP, 71, Pt. 2: Washington (U.S. Govt. Printing Office), 667-686.

Date of initial receipt: 16 March 1990

Date of acceptance: 9 November 1990

Ms 120B-192 

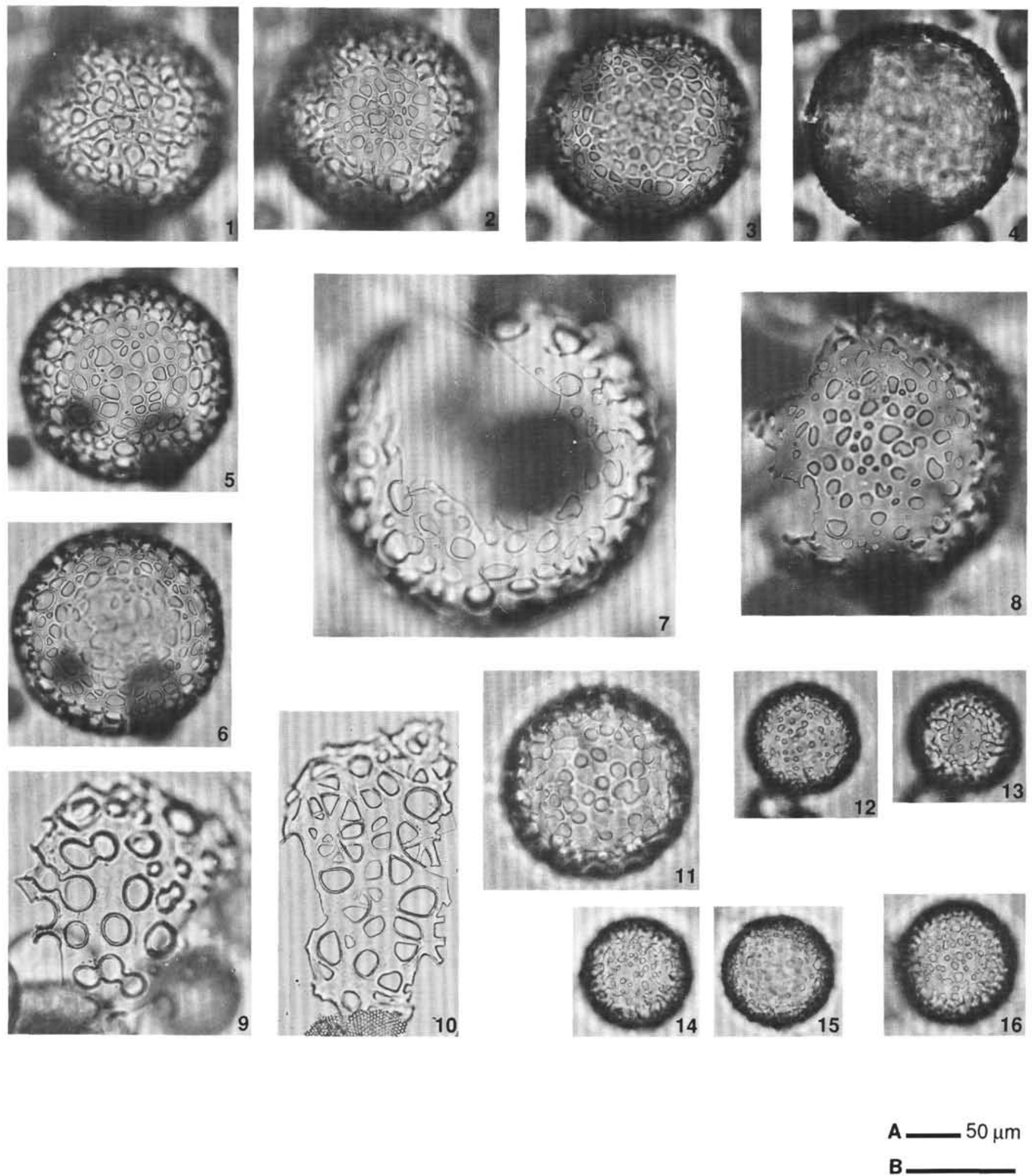

Plate 1. Stage coordinates of specimens (label to left, Zeiss standard microscope) follow each sample name. Magnifications given by Scales A and $\mathrm{B}$ on each plate. All type specimens are individually marked on slides and deposited in the paleontological collections of the Geologisches Institut, ETH Zürich. 1-10. Acrosphaera? labrata, n. sp.; (1-4) holotype, Sample 120-751A-5H-4, $48 \mathrm{~cm}, 81.4 / 32.7 ;(5-6) 81.5 / 38.7 ;$ (7) Sample 120-746A-4H-4, $53 \mathrm{~cm}, 83.2 / 25.6$; (8), Sample 120-746A-4H-6, $53 \mathrm{~cm}, 83.4 / 42.7$; (9) Sample 120-746A-4H-1, 53 cm, 84.0/42.0; (10) 83.8/36.8. 11-16. Acrosphaera? mercurius n. sp.; (11) holotype, Sample 120-747B-4H-3, $112 \mathrm{~cm}, 81.4 / 24.5$; (12-13) Sample 120-751A-5H-2, 49 cm, $80.9 / 6.8$; (14-15), Sample 120-746A-4H-1, $53 \mathrm{~cm}, 83.1 / 27.0$; (16) 82.8/27.5. Magnifications: Figures 7 and 9-11 are Scale B; the rest are Scale A. 

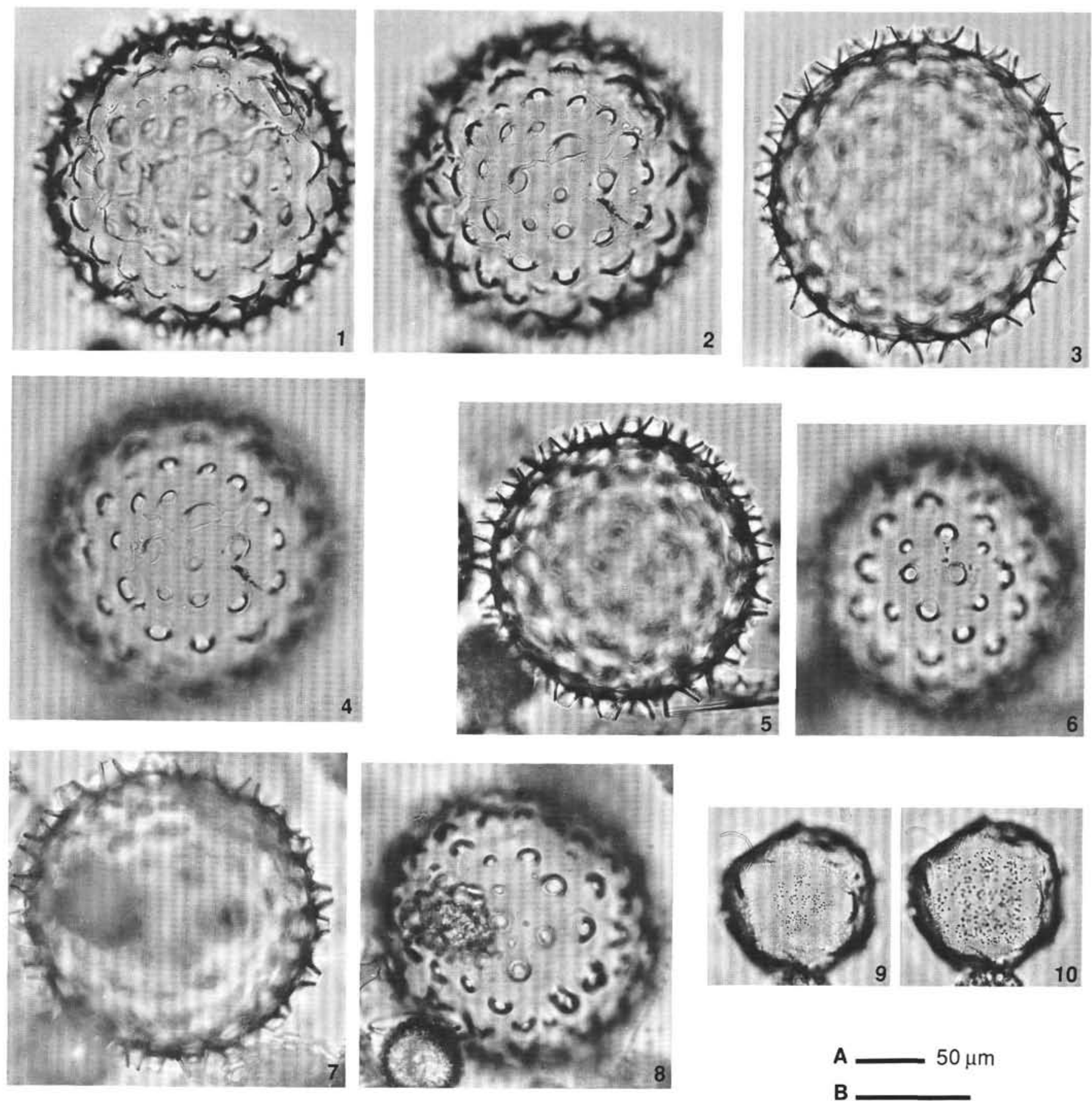

Plate 2. See Plate 1 for specifications. 1-8. Siphonosphaera vesuvius $\mathrm{n} . \mathrm{sp}$.; (1-4) holotype, Sample 120-747A-5H-3, 112 cm, 2.9/83.1; (5-6) 3.3/86.5; (7-8) 17.0/67.5. 9-10. Siphonosphaera magnisphaera, Sample 120-751A-12H-6, $98 \mathrm{~cm}, 83.8 / 17.4$. Magnifications: All figures are Scale A. 

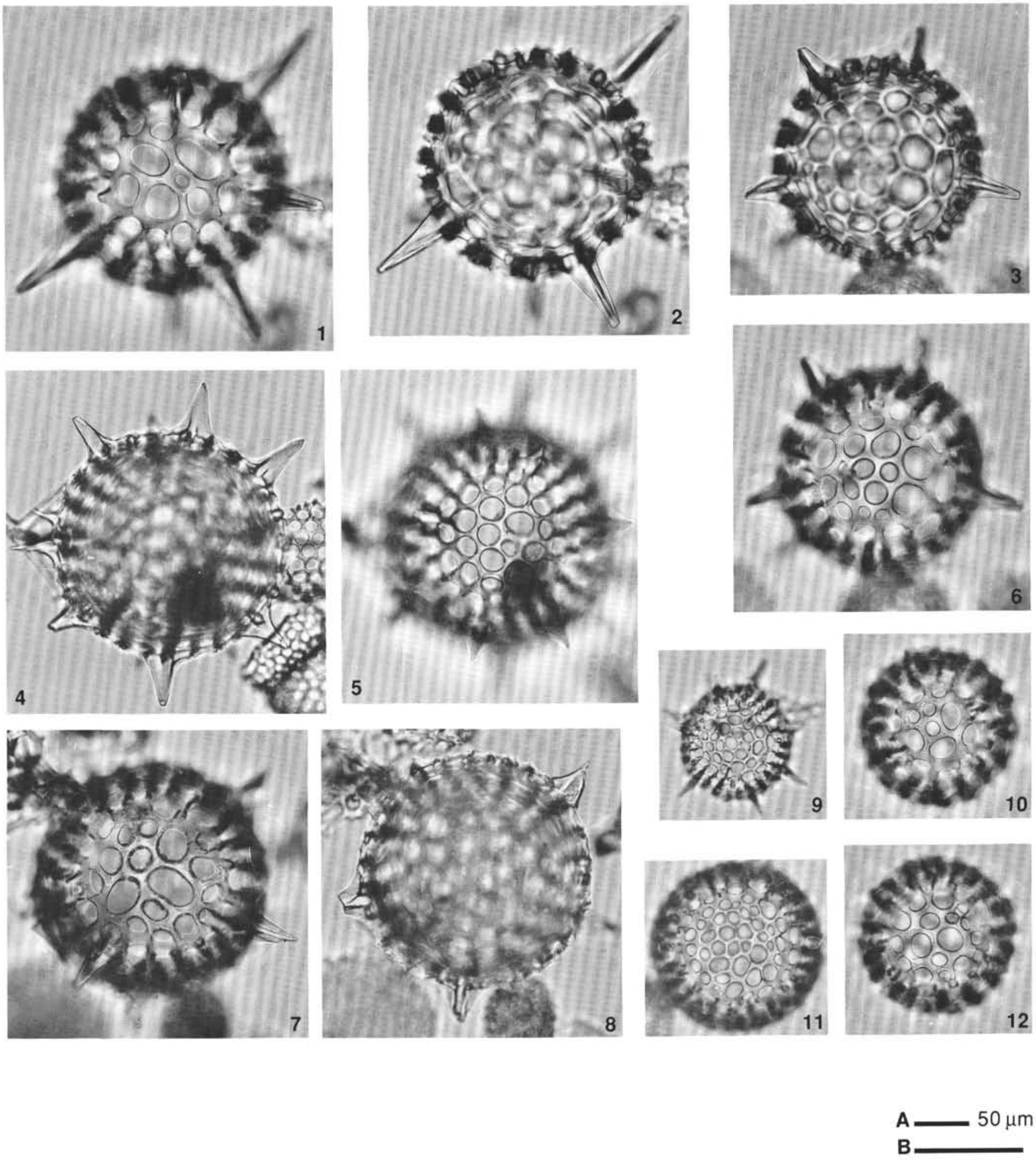

Plate 3. See Plate 1 for specifications. 1-9. Actinomma? magnifenestra $\mathrm{n} . \mathrm{sp}$; $(1-2)$ holotype, Sample $120-747 \mathrm{~A}-6 \mathrm{H}-4,45 \mathrm{~cm}, 11.5 / 102.0 ;(3$, 6) 8.5/91.5; (4-5) Sample 120-747A-8H-4, 45 cm, 85.2/15.0; (7-8) Sample 120-747A-6H-4, 45 cm, 10.5/96.8; (9) Sample 120-747A-8H-4, 45 cm, 88.5/23.0. 10-12. A.? magnifenestra?; (10) Sample 120-747A-6H-4, $45 \mathrm{~cm}$; (11) Sample 120-744A-9H-1, 60-62 cm, 104.1/23.5; (12) Sample 120-747A-6H-4, $45 \mathrm{~cm}, 14.2 / 107.7$. Magnifications: All figures are Scale A, except for Figure 9, which is $0.5 \cdot$ Scale A. 

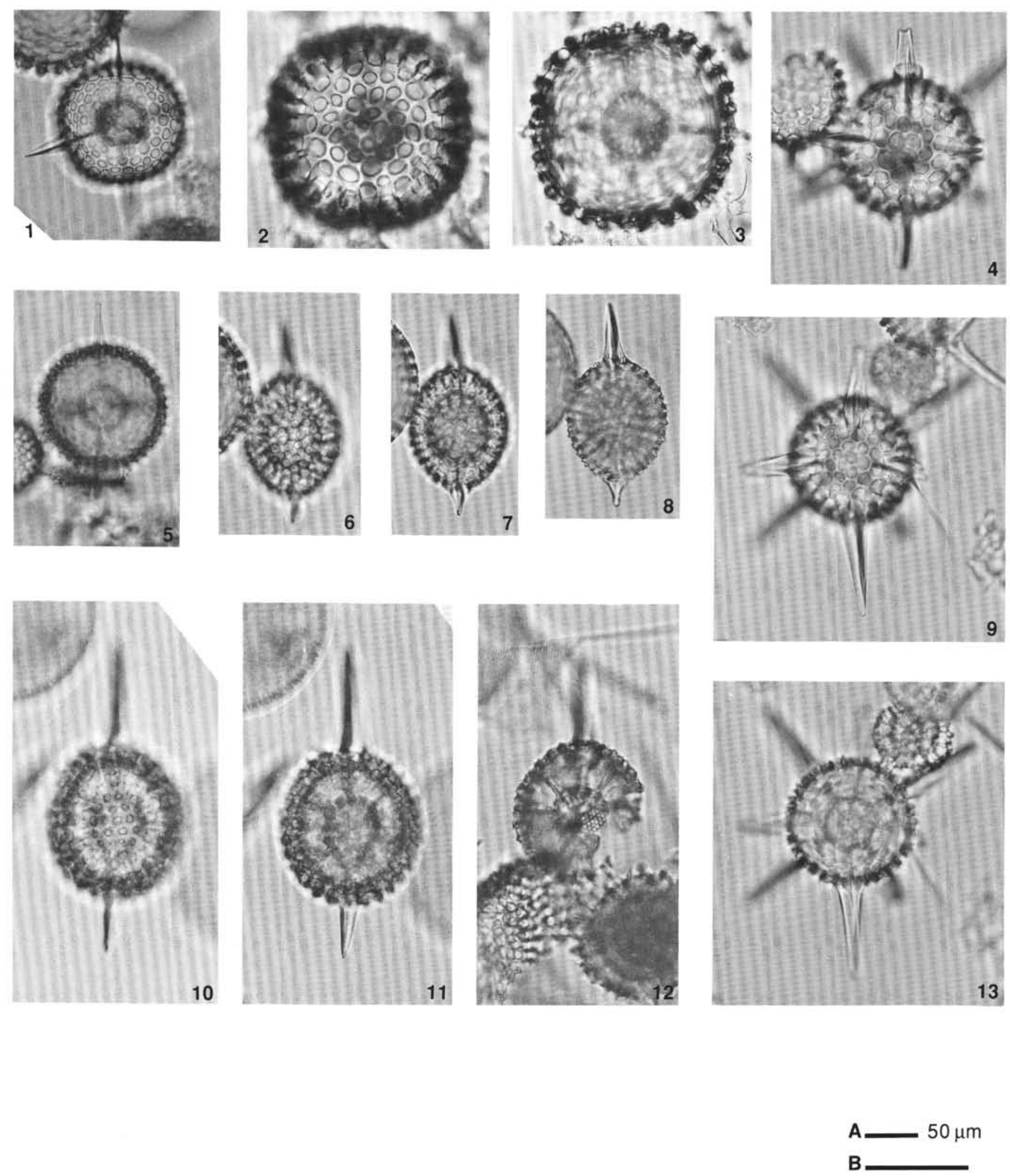

Plate 4. See Plate 1 for specifications. 1-3, 5. Hexalonche philosophica?; (1) Sample 120-748B-7H-6, $45 \mathrm{~cm}, 90.9 / 24.2 ;(2-3)$ Sample 120-744A-10H-1, $60 \mathrm{~cm}, 82.5 / 40.8$; (5) Sample 120-748B-7H-6, 45 cm, 88.3/23.8. 6-8. S. santaennae, Sample 120-747A-9H-2, 90 cm, 87.3/27.0. 10-12. L. timmsi?; (10-11) Sample 120-746A-4H-6, $53 \mathrm{~cm}, 82.8 / 36.4$; (12) 80.9/32.1. 4, 9, 13. Actinomma sp. (ancestor to A. golownini?); (4) Sample 120-751A-12H-5, $98 \mathrm{~cm}, 83.2 / 35.8 ;(9,13)$ 83.5/36.5. Magnifications: Figures $2-3$ and $10-12$ are Scale B; the rest are Scale A. 

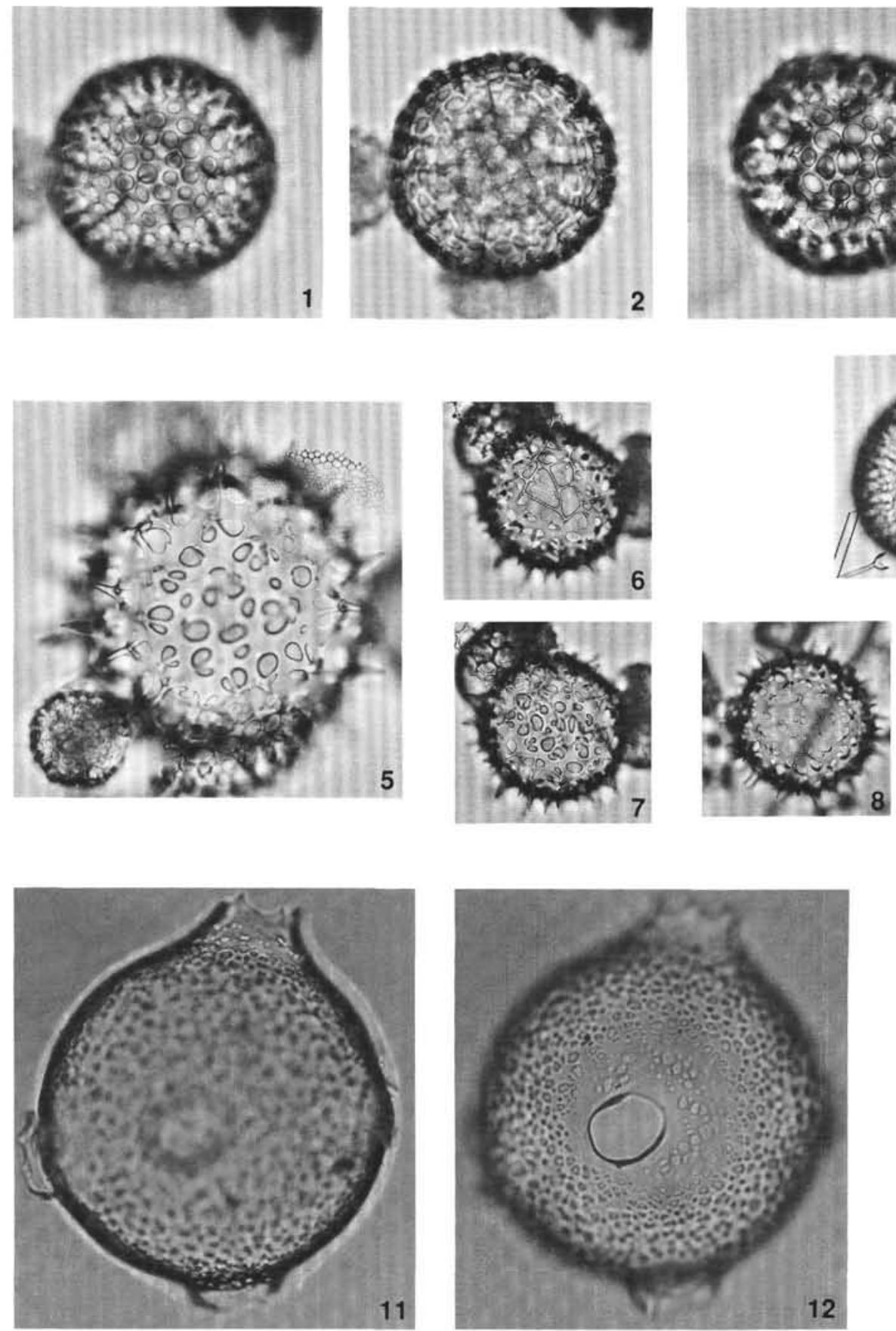
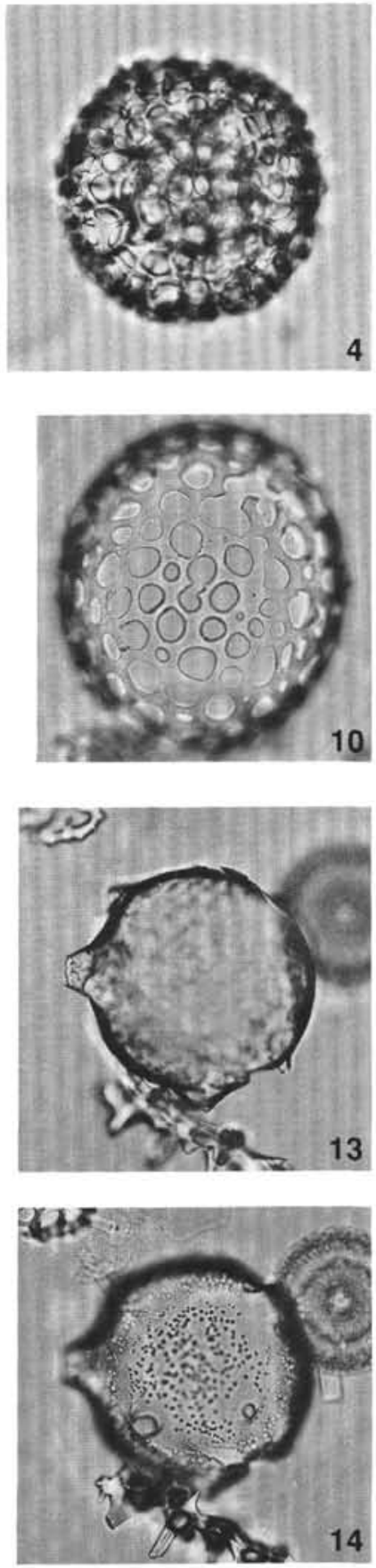

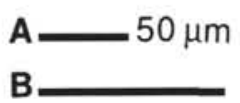

Plate 5. See Plate 1 for specifications. 1-4. Spongoplegma sp. Chen; (1-2) Sample 120-747B-5H-4, 112 cm, 82.5/17.4; (3-4) Sample 120-747A-5H-3, $112 \mathrm{~cm}, 82.3 / 31.9 .5-8$. Acrosphaera spinosa echinoides Haeckel; (5) Sample 120-744A-8H-2, 60 cm, 82.6/33.9; (6-7) Sample 120-744A-10H-4, $60 \mathrm{~cm}, 82.0 / 28.2$; (8) 83.3/15.1. 9-10 Collosphaerid spp.; (9) Sample 120-751A-10H-6, 98 cm, Piece 1, 90.4/20.9; (10) Sample 120-747A-8H-4, $45 \mathrm{~cm}, 88.1 / 13.9$. 11-14. Solenosphaera magnisphaera; (11-12) recent specimen from a Panama Basin sediment trap, $3791 \mathrm{~m}$ water depth (specimen courtesy Dr. Kozo Takahashi, WHOI); (13-14) Sample 120-751A-12H-6, 98 cm, Piece 1, 85.7/15.4. Magnifications: Figures 1-5 and 11-12 are Scale B; the rest are Scale A. 


\section{LAZARUS}
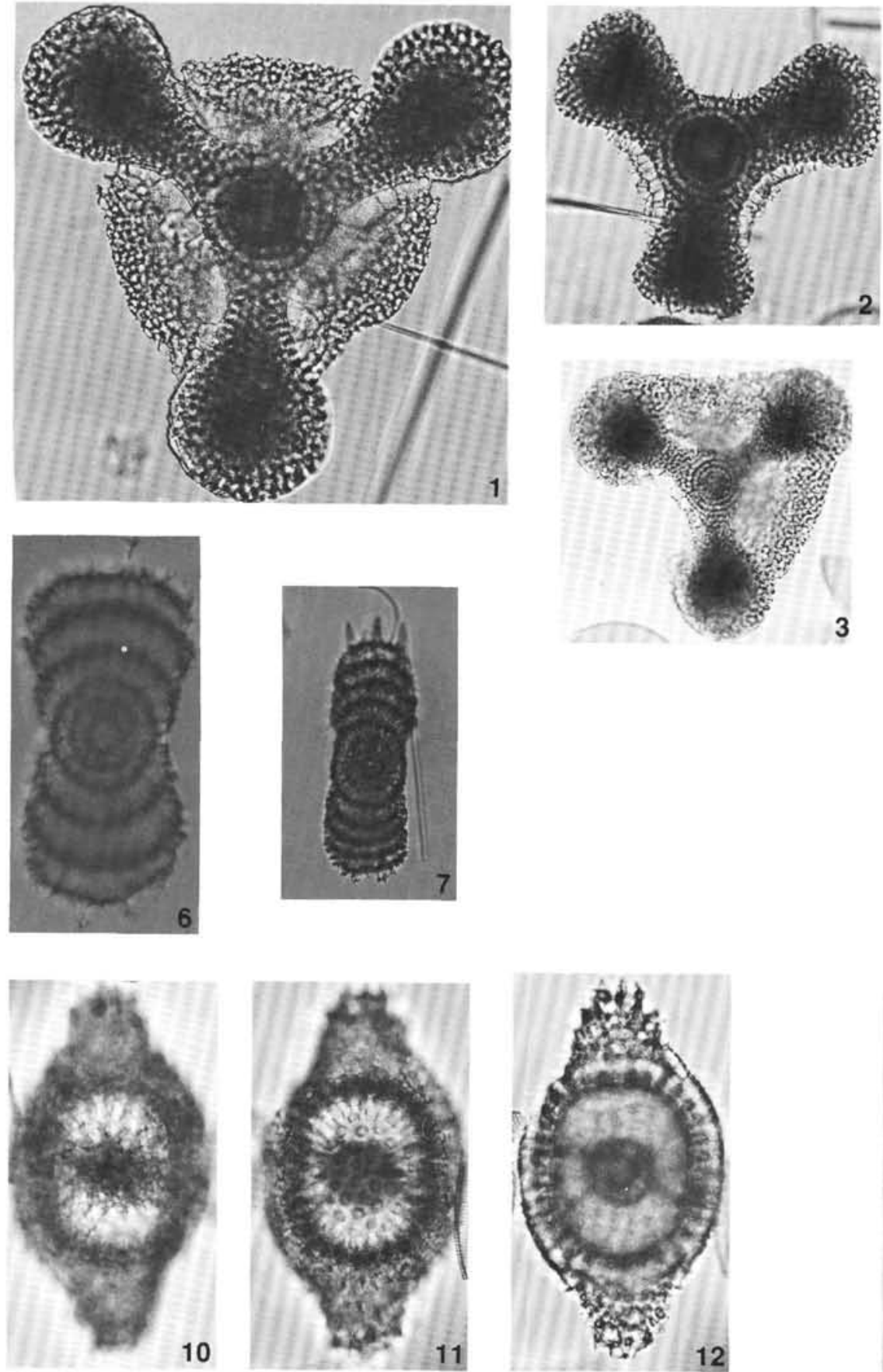
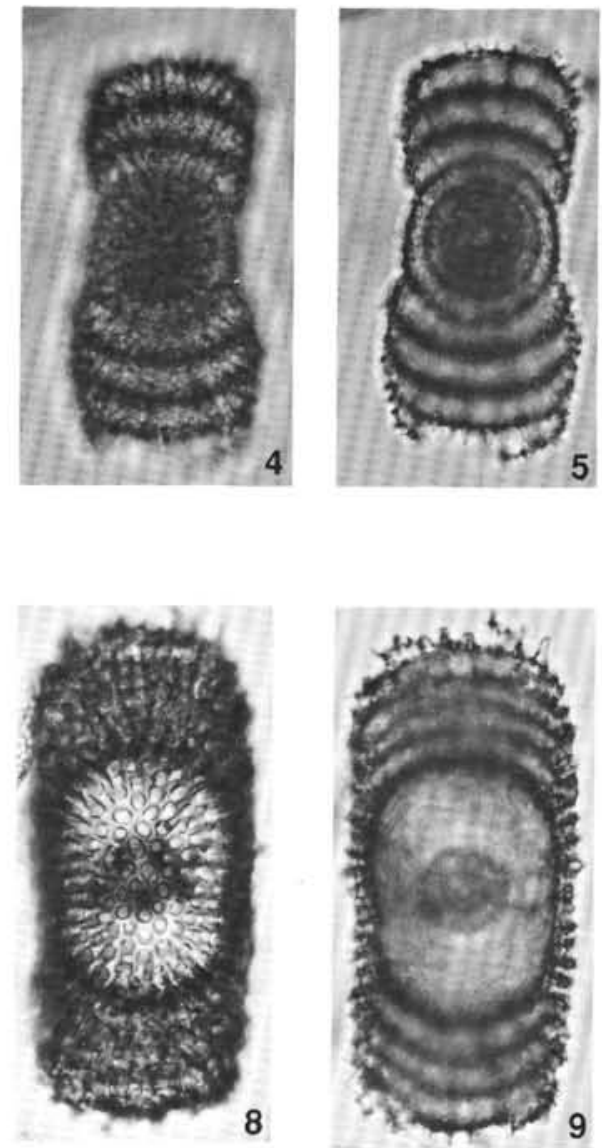

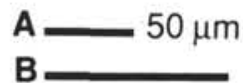

Plate 6. 1-3. Rhopalastrum sp. 1, Sample 120-747B-6H-3, $32 \mathrm{~cm}, 81.7 / 23.6$; (2) Sample 119-737B-7H-1, $53 \mathrm{~cm}, 103.2 / 12.8$; (3) Sample 119-737A-27X-2, 53 $\mathrm{cm}$, Piece 1, 84.8/36.2. 4-7. Amphymenium challengerae; (4-5) Sample 120-747A-4H-4, $45 \mathrm{~cm}, 91.8 / 17.8$; (6-7) Sample 119-745B-24X-6, 53-55 cm. 8-9. Diartus sp., Sample 119-737A-27X-2, $53 \mathrm{~cm}$, Piece 2, 82.1/34.7. 10-14. Didymocyrtis sp.; (10-12) Sample 120-747A-5H-3, 112 cm, 84.1/20.4; (13-14) Sample 119-737A-26X-1, $94 \mathrm{~cm}$, Piece 1 94.7/25.8. Magnifications: Figure 1 is Scale B; all of the other figures are Scale A. 

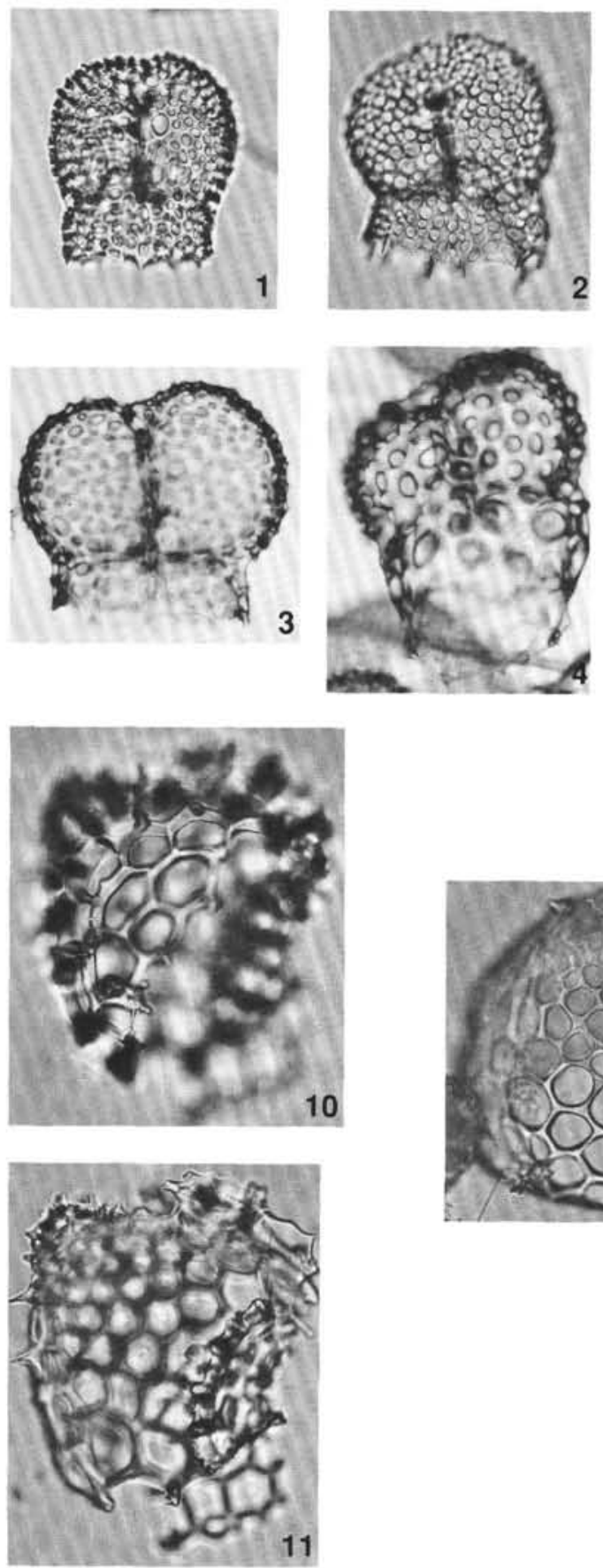
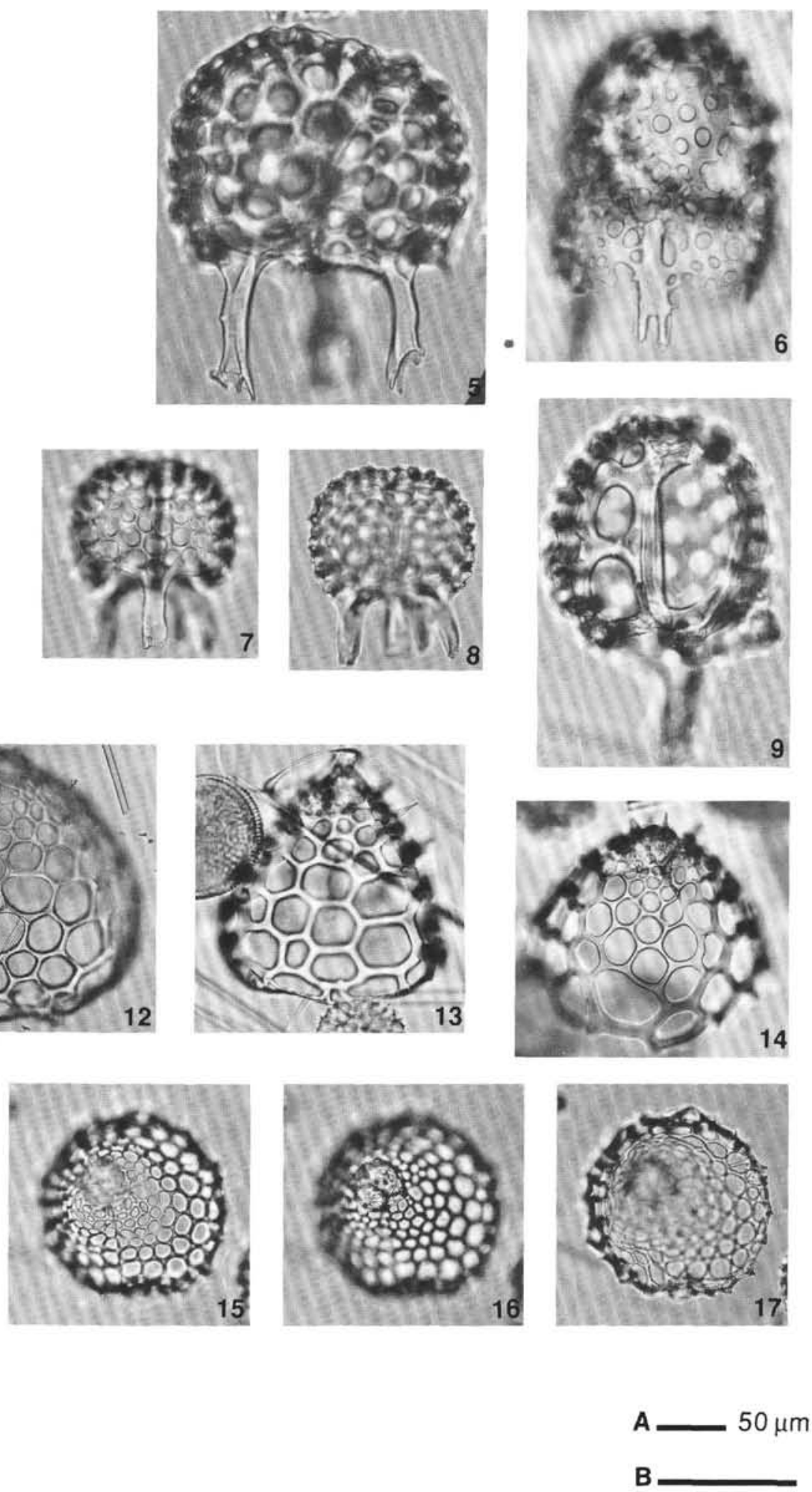

Plate 7. 1-2. Dendrospyris megalocephalis?; (1) Sample 120-747B-5H-6, $32 \mathrm{~cm}, 82.8 / 13.4$; (2) Sample 120-747B-5H-6, 112 cm, 80.6/19.5. 3-4. Desmo-spyris rhodospyroides; (3) DSDP XX-329-13-CC; (4) DSDP XX-278-13-1, $140 \mathrm{~cm}$. 5-9. Triceraspyris coronata; (5) Sample 120-747B-6H-4, $32 \mathrm{~cm}, 89.2 / 9.1$; (6) Sample 120-746A-5H-1, 53-55 cm, 82.3/21.7; (7-8) Sample 120-747A-4H-4, 45 cm, 42.8/83.2; (9) Sample 120-747B-6H-3, $113 \mathrm{~cm}, 86.2 / 40.8$. 10-17. Ceratocyrtis sp.; (10-11) Sample 120-744A-10H-1, $60 \mathrm{~cm}, 85.0 / 35.2 ;$ (12) Sample 120-744A-9H-1, 60 cm, 103.6/37.7; (13) Sample 120-751A-9H-2, 98 cm, Piece 1, 81.0/17.3; (14) Sample 120-746A-8H-1, 53 cm, 82.1/17.8; (15-17) Sample 120-744A-9H-1, $60 \mathrm{~cm}, 97.8 / 15.1$. Magnifications: Figures 5, 6, and 9 are Scale B; the rest are Scale A (except for Figures 3 and 4, for which the scale is unknown). 

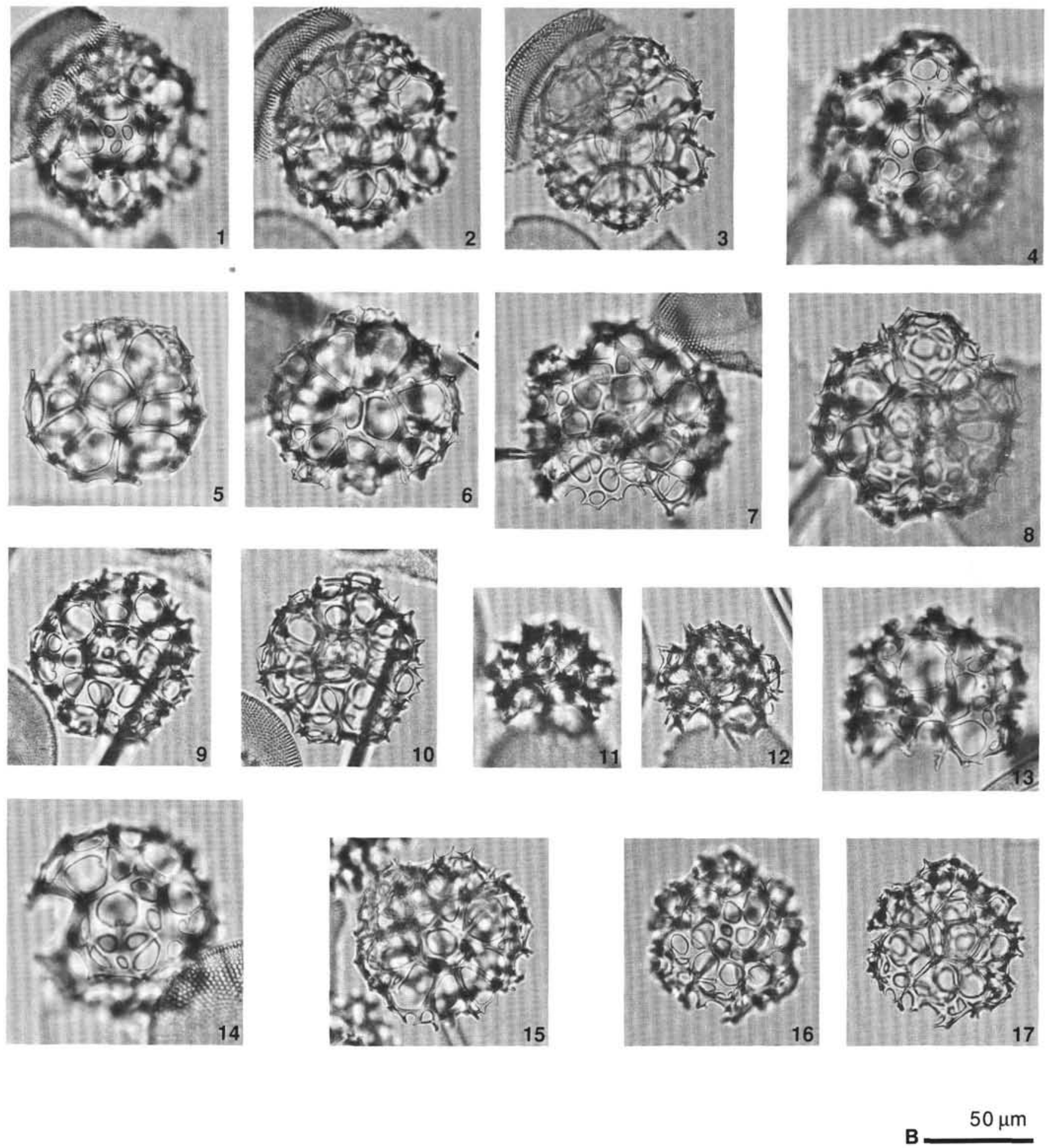

Plate 8. 1-17. Helotholus? haysi $\mathrm{n}$. sp.; (1-3) holotype, Sample 120-746A-8H-3, 53-55 cm, 81.1/9.2; (4) Sample 120-746A-16H-1, 53 cm, 82.9/24.8; (5) Sample 120-746A-8H-1, 53 cm, 84.2/11.6; (6) Sample 120-746A-8H-3, $53 \mathrm{~cm}, 81.9 / 12.3$; (7) 81.4/8.8; (8) Sample 120-746A-16H-1, $53 \mathrm{~cm}, 82.9 / 24.8$; (9-10) Sample 120-746A-11H-3, $53 \mathrm{~cm}, 83.0 / 36.3$; (11-12) Sample 120-746A-16H-1, 53 cm, 85.1/35.1; (13) Sample 120-746A-8H-3, $53 \mathrm{~cm}, 82.2 / 36.8$; (14) 80.9/31.7; (15) Sample 120-746A-11H-1, $53 \mathrm{~cm}, 82.4 / 19.0$; (16-17) Sample 120-746A-6H-4, 53 cm, 82.9/19.9. Magnifications: All figures are Scale B. 

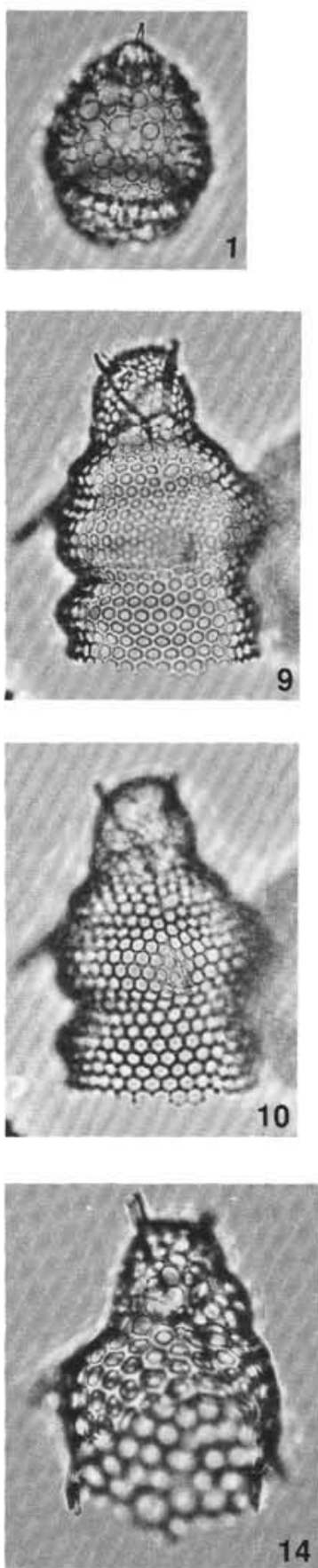
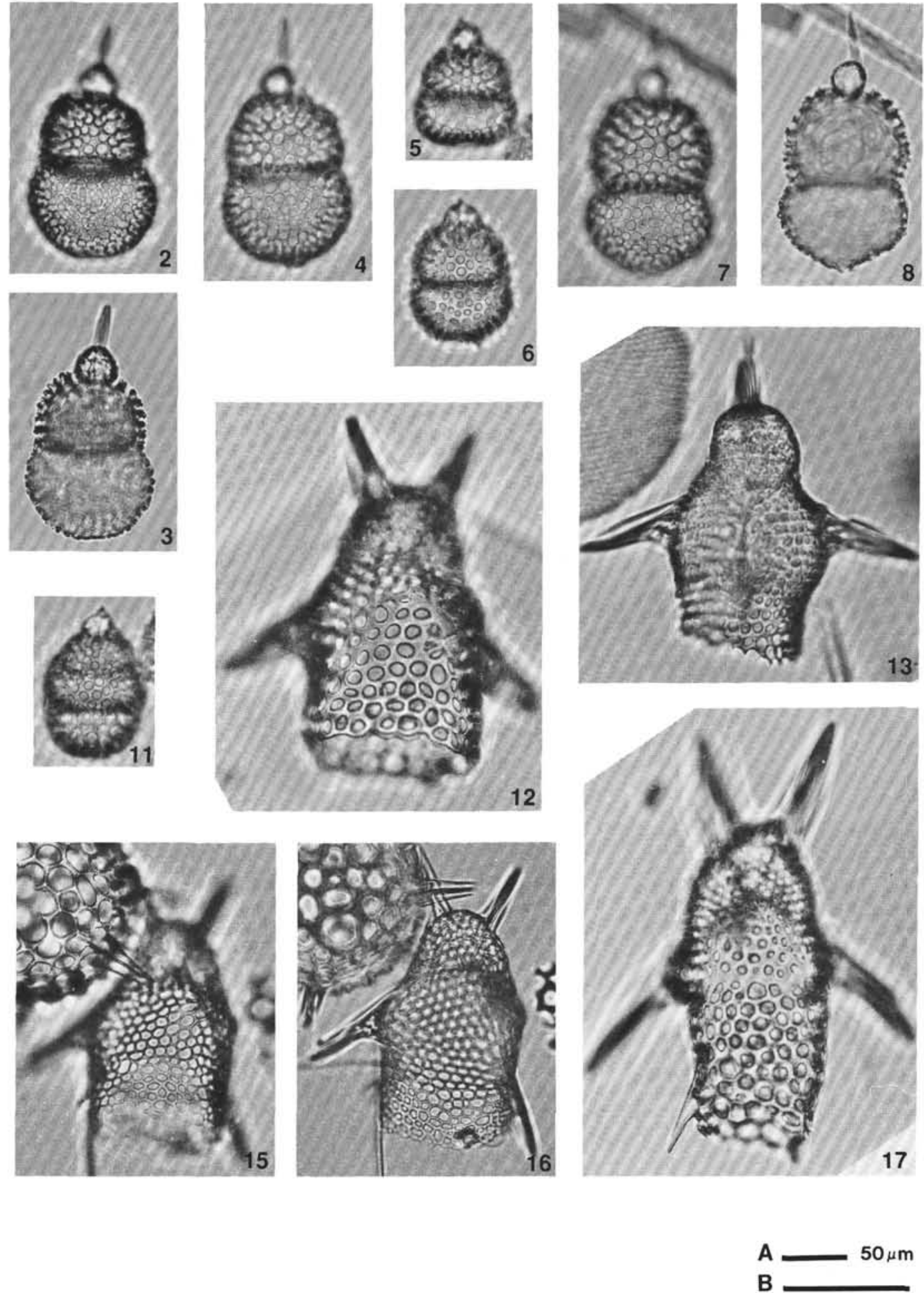

Plate 9. 1-8. Cyrtocapsella japonica; (1) Sample 120-747A-9H-2, $40 \mathrm{~cm}, 90.5 / 33.6$; (2-3) Sample 120-747A-8H-4, 45 cm, 82.5/24.8; (4) 87.0/41.3; (5) Sample 120-747B-6H-7, $16 \mathrm{~cm}, 81.0 / 42.1$; (6) 82.4/28.3; (7-8) Sample 120-747A-8H-4, $45 \mathrm{~cm}, 87.5 / 14.8$. 11. Cyrtocapsella tetrapera, Sample 120-747A-9H-2, $40 \mathrm{~cm}, 83.3 / 37.4$. 9-10, 12-17. Stichopileum bicorne?; (9-10) Sample 120-751A-6H-1, 53 cm, 83.2/22.0; (12) Sample 120-744A-8H-2, $60 \mathrm{~cm}, 81.3 / 35.0$; (13) Sample 120-746A-7H-2, $53 \mathrm{~cm}, 81.3 / 11.5$; (14) Sample 120-747B-6H-6, 113 cm, 86.6/15.5; (15-16) Sample $120-744$ A-9H-1, $60 \mathrm{~cm}, 100.8 / 41.0$; (17) Sample 120-744A-7H-4, $60 \mathrm{~cm}, 82.0 / 36.2$. Magnifications; Figures $1-8$ and 11 are Scale A; the rest of the figures are Scale B. 